\title{
MeCP2 Repression of G9a in Regulation of Pain and Morphine Reward
}

\author{
(D)Zhi Zhang, ${ }^{1,2}$ Wenjuan Tao, ${ }^{2}$ Yuan-Yuan Hou, ${ }^{1}$ Wei Wang, ${ }^{1}$ Paul J. Kenny, ${ }^{3}$ and Zhizhong Z. Pan ${ }^{1}$ \\ ${ }^{1}$ Department of Anesthesiology and Pain Medicine, The University of Texas MD Anderson Cancer Center, Houston, Texas 77030, ${ }^{2}$ Key Laboratory of Brain \\ Functions and Diseases, School of Life Science, University of Science and Technology of China, Hefei, Anhui 230027, China, and ${ }^{3}$ Department of \\ Pharmacology and Systems Therapeutics, Icahn School of Medicine at Mount Sinai, New York, New York 10029
}

Opioids are commonly used for pain relief, but their strong rewarding effects drive opioid misuse and abuse. How pain affects the liability of opioid abuse is unknown at present. In this study, we identified an epigenetic regulating cascade activated by both pain and the opioid morphine. Both persistent pain and repeated morphine upregulated the transcriptional regulator MeCP2 in mouse central nucleus of the amygdala (CeA). Chromatin immunoprecipitation analysis revealed that MeCP2 bound to and repressed the transcriptional repressor histone dimethyltransferase G9a, reducing G9a-catalyzed repressive mark H3K9me2 in CeA. Repression of G9a activity increased expression of brain-derived neurotrophic factor (BDNF). Behaviorally, persistent inflammatory pain increased the sensitivity to acquiring morphine-induced, reward-related behavior of conditioned place preference in mice. Local viral vector-mediated MeCP2 overexpression, Cre-induced G9a knockdown, and CeA application of BDNF mimicked, whereas MeCP2 knockdown inhibited, the pain effect. These results suggest that $\mathrm{MeCP} 2$ directly represses $\mathrm{G} 9 \mathrm{a}$ as a shared mechanism in central amygdala for regulation of emotional responses to pain and opioid reward, and for their behavioral interaction.

Key words: G9a; MeCP2; opioid; pain; reward

\section{Introduction}

Opioid analgesics are widely used for relieving pain in clinical pain management. Opioids also have strong rewarding and addictive effects after repeated use. In clinical practice, it has long been a disturbing issue how pain affects abuse liability of prescription opioids in patients taking repeated opioids for pain control. In fact, non-medical abuse of prescription opioids is rapidly arising in recent years, including incidences of illicit opioid use and behaviors of problematic opioid misuse among chronic pain patients under opioid therapy (Woolf and Hashmi, 2004; Ballantyne and LaForge, 2007; Passik and Kirsh, 2011). However, few preclinical or clinical studies have addressed the interaction of pain and rewarding effects of prescription opioids. Previous animal studies on a related topic were mainly intended to use opioid consumption as an alternative measurement for different dimensions of pain behaviors (Martin and Ewan, 2008; King et al., 2009). The neurobiological mechanisms by which

\footnotetext{
Received Sept. 30, 2013; revised May 22, 2014; accepted May 30, 2014.

Author contributions: Z.Z., Y.-Y.H., and Z.Z.P. designed research; Z.Z., W.T., Y.-Y.H., and W.W. performed research; P.J.K. contributed unpublished reagents/analytic tools; Z.Z., W.T., Y.-Y.H., W.W., and Z.Z.P. analyzed data; Z.Z., P.J.K., and Z.Z.P. wrote the paper.

This work was supported by National Institutes of Health-National Institute on Drug Abuse grants DA023069 and DA027541 to Z.Z.P. and DA025983 to P.J.K., and by National Natural Science Foundation of China (31100802 and 91332109) and Development Program of Basic Research of China (2014CB548100) to Z.Z. We thank Dr. Huda Zoghbi for providing the MeCP2-TG mouse strain.

The authors declare no financial conflict of interest.

Correspondence should be addressed to Zhizhong Z. Pan, Ph.D., Department of Anesthesiology and Pain Medicine, The University of Texas MD Anderson Cancer Center, 1515 Holcombe Boulevard, Unit 110, Houston, TX 77030. E-mail:zzpan@mdanderson.org.

DOI:10.1523/JNEUROSCI.4194-13.2014

Copyright $\odot 2014$ the authors $\quad 0270-6474 / 14 / 349076-12 \$ 15.00 / 0$
}

behavioral responses to pain and opioid reward are regulated remain unexplored.

A potentially important link between pain and opioid reward is emotion processing, as pain is often associated with a negative affective state whereas drug reward induces positive euphoric emotion (Koob et al., 2004; Hyman et al., 2006; Neugebauer et al., 2009). The amygdalar complex, including the central nucleus of the amygdala (CeA), is a major brain structure for control and integration of emotional responses to positive (e.g., reward) and aversive (e.g., fear and pain) environmental stimuli (Pitkänen et al., 1997). Indeed, CeA mediates both drug reward-related positive emotional behaviors (Baxter and Murray, 2002; Gottfried et al., 2003; See et al., 2003) and negative emotional states of affective pain (Fields, 2004; Neugebauer et al., 2009). Thus, removal of pain-associated aversive state by analgesics can be rewarding (negative reinforcement) and induce reward-related behavior of conditioned place preference (CPP) in animals (Fields, 2004; King et al., 2009), a process regulated likely through emotion interaction involving CeA.

The methyl CpG-binding protein 2 (MeCP2), which binds to methylated $\mathrm{CpG}$ sites of DNA, is originally known as a prominent transcriptional repressor and disruptive mutations in $\mathrm{MeCP} 2$ cause the neurodevelopmental disorder Rett syndrome. Recent studies show that $\mathrm{MeCP} 2$ can act as a transcriptional repressor or activator and has a diverse role in the pathogenesis of several neurological diseases (Chahrour et al., 2008; Guy et al., 2011). For instance, $\mathrm{MeCP} 2$ plays an important role in regulating motivational effects of cocaine and psychostimulants (Deng et al., 2010; Im et al., 2010); it also has been implicated in modulation of pain behaviors in animals (Géranton et al., 2007; Tochiki et al., 2012). 
The molecular mechanisms for these $\mathrm{MeCP} 2$ roles are just beginning to be understood and importantly, the direct targets of $\mathrm{MeCP} 2$ in its transcription regulation remain largely unclear.

In this study, we investigated the role of MeCP2 in CeA regulation of responses to pain and to opioid reward in animal models of chronic pain, and determined molecular targets of CeA $\mathrm{MeCP} 2$ in its regulation of pain and opioid reward.

\section{Materials and Methods}

Animals. MeCP2-TG female mice on FVB background containing one copy of the human $\mathrm{MeCP} 2$ transgene were mated to wild-type (WT) males on C57BL6 background. G9a-floxed mice (The Jackson Laboratory) were fully backcrossed to C57BL/6J mice. All procedures involving the use of animals conformed to the guidelines by the University of Texas MD Anderson Cancer Center Animal Care and Use Committee.

Animal model of inflammatory pain. Complete Freund's adjuvant (CFA; $40 \mu \mathrm{l}$; Sigma-Aldrich) or saline was injected into the plantar surface of one hindpaw of a mouse under brief halothane anesthesia. Pain thresholds were measured by the paw-withdrawal test with the Hargreaves' analgesia apparatus (Stoelting) for thermal hyperalgesia, or with von Frey filaments for mechanical allodynia, on a freely moving mouse. The antinociceptive effect of an infused drug was measured 10-20 min post infusion.

Microinjection. Under Nembutal anesthesia, a mouse was implanted with a 26 gauge guide cannula (Plastics One) aiming CeA (anteroposterior: $-0.94 \mathrm{~mm}$ from the bregma; lateral: $\pm 2.55 \mathrm{~mm}$; ventral: $4.75 \mathrm{~mm}$ from dura). Lentivirus vectors expressing GFP (lenti-controls and lentish-MeCP2, with viral supernatant concentrations ranging from $3 \times 107$ to $5 \times 109$ infection units per milliliter, $1 \mu \mathrm{l}$ ) were bilaterally infused into CeA through a 33 gauge injector with an infusion pump $(0.05 \mu \mathrm{l} / \mathrm{min}) 4$ weeks before experiments. Adeno-associated virus (AAV)-EF1amCherry-IRES-WGA-Cre ( $1 \mu \mathrm{l}$; University of North Carolina vector core facility) was similarly infused 3 weeks before. UNC0224 (0.7 ng/ side), BIX01294 (60 ng/side), BDNF (1 ng/side), or TrkB-IgG (50 ng/ side) in $0.5 \mu \mathrm{l}$ was infused into CeA $2-4 \mathrm{~h}$ before tests. All infusion sites in CeA were historically verified afterward by injecting a blue dye in $0.5 \mu \mathrm{l}$ and off-site controls ( $n=3$ mice) were performed to confirm site specificity, as we described previously (Bie et al., 2009; Cai et al., 2013).

CPP. In a two-chamber CPP apparatus (MED Associates), a mouse was habituated and then conditioned for $30 \mathrm{~min}$ with saline or morphine $(0.1-1 \mathrm{mg} / \mathrm{kg}$, i.p.) in a single daily session of saline paired with one chamber in the morning and morphine paired with the other chamber in the afternoon for $3 \mathrm{~d}$ to induce CPP behavior. A CPP test ( $15 \mathrm{~min}$ ) before the conditioning (pretest) determined the baseline preference, and mice that spent $>60 \%$ of total time in one chamber (equipment bias) were excluded from the study for an unbiased CPP paradigm. After the conditioning sessions, CPP was measured by a CPP test (post-test, $15 \mathrm{~min}$ ) and CPP scores were calculated by subtracting the time of pretest from that of post-test in the morphine-paired chamber. CFA was injected $3 \mathrm{~d}$ before the conditioning.

Open field test. Mice were habituated in an open field apparatus consisting of a square area $(81 \mathrm{~cm} \times 81 \mathrm{~cm})$ for 1 week before tests. In an open field test, a mouse was placed in the same corner and locomotor activity was observed for $5 \mathrm{~min}$ to record the distance it traveled. Seventyfive percent ethanol was used to remove the cues in the apparatus during the interval of tests. The test was conducted $1 \mathrm{~d}$ before and $3 \mathrm{~d}$ after intraplantar injection of saline or CFA.

Western blotting. CeA tissues were homogenized in $100 \mu \mathrm{l}$ RIPA lysis buffer with fresh protease inhibitors. The lysates were centrifuged and the supernatant was used for SDS-PAGE. Membranes were incubated in solutions containing an antibody to MeCP2 (1:2000; Cell Signaling Technology), G9a (1:1000; Millipore), histone 3 dimethyl lys9 (H3K9me2; 1:500; Active Motif), EHMT1/GLP1 (1:1000; Millipore), Enhancer of zeste homolog 2 (EZH2; 1:1000; Cell Signaling Technology), REST (1: 500; Millipore), BDNF (1:200; Santa Cruz Biotechnology), NGF (1:200; Santa Cruz Biotechnology), $\kappa$ opioid receptor (1:1000; Abcam), Dynorphin A (1:200; Abcam), $\mathrm{K}^{+} / \mathrm{Cl}^{-}$cotransporter (1:2000; Millipore), corticotropin-releasing factor (1:200; Santa Cruz Biotechnology), $\beta$-tubulin (1:2000; Cell Signaling Technology), or GAPDH (1:2000; Cell Signaling Technology). Membranes were incubated in secondary antibody to rabbit HRP $(1: 10,000)$ or to mouse Ig HRP $(1: 20,000$; Calbiochem).

Chromatin immunoprecipitation assays. CeA tissues were harvested and immediately cross-linked in 1\% formaldehyde for 15-20 min. After washes, the CeA tissue was homogenized 10-30 strokes in a cell lysis buffer. The homogenate was centrifuged and the supernatant was removed. The extracted chromatin was sheared by sonication into $200-$ $500 \mathrm{bp}$ fragments and was diluted tenfold in chromatin immunoprecipitation (ChIP) dilution buffer. Normal mouse IgG immunoprecipitates with a mouse polyclonal anti-IgG antibody were used as control to normalize appropriate enrichment of signal amplification, and the data were presented after being normalized to saline/WT control groups. Samples were incubated with an antibody to MeCP2 (Cell Signaling Technology), G9a (Millipore), or H3K9me2 (Novus Biologicals). DNA and histones were dissociated with reverse buffer. Binding buffer was used for DNA precipitation and purification, and elution buffer was used to elute purified DNA from the columns. All buffers were provided in the ChIP kit.

DNA quantification. Quantitative real-time (RT)-PCR with SYBR Green Master kit (Applied Biosystems) was used to measure the amount of MeCP2-, G9a-, and H3K9me2-associated DNA with adenine phosphoribosyltransferase (house-keeping mRNA) as negative control. Signal difference was calculated by: $\Delta \mathrm{Ct}=\left(N_{\exp }-N_{\text {ave }}\right) \times \mathrm{Ct}_{\text {ave }}\left(N_{\exp }\right.$, normalized Ct value of the target or $\mathrm{Ct}_{\text {target }} / \mathrm{Ct}_{\text {input }} ; N_{\text {ave }}$, mean $N$ value for control; and $\mathrm{Ct}_{\mathrm{ave}}$, mean Ct value for control).

Quantitative RT-PCR. RNA was extracted with the RNAqueous-4PCR Kit and reverse transcribed with the RETROscript Kit (Applied Biosystems). cDNA was quantified by RT-PCR and specific cDNA regions of the transcripts were amplified with custom-designed primers (Invitrogen). Fold differences of mRNA levels over controls were calculated by $\Delta$ Ct. The following primers were used: $G 9 a$, forward 5' TGCCTATGT GGTCAGCTCAG-3', reverse $5^{\prime}$-GGTTCTTGCAGCTTCTCCAG-3'; $B d n f$, forward $5^{\prime}$-GAGGGCTCCTGCTTCTCAA-3', reverse 5'-GCC TTCATGCAACCGAAGT-3'; Mecp 2, forward 5' -CGCTCCGCCCTATC TCTGA-3', reverse 5'-ACAGATCGGATAGAAGACTC-3'; Gapdh, forward 5' - AGGTCGGTGTGAACGGATTTG-3', reverse 5'-TGTAG ACCATGTAGTTGAGGTCA-3'.

Data analysis and materials. ANOVA (one-way and two-way) and post hoc analysis were used to statistically analyze experimental data between treatment groups with multiple comparisons. Simple comparisons of data between two groups were made with the unpaired Students' $t$ test. Behavioral data with multiple measurements were statistically analyzed by two-way ANOVA for repeated measures with the Bonferroni method for post hoc tests. Data are presented as mean \pm SEM and $p<0.05$ was considered statistically significant. All statistical analyses were performed with the Prism software version 5.04 (GraphPad Software). Drugs were purchased from Sigma-Aldrich or Tocris Bioscience.

\section{Results}

\section{Acquisition of reward behavior is facilitated in pain conditions}

We used a mouse model of persistent inflammatory pain induced by an injection of CFA $(40 \mu \mathrm{l})$ into a hindpaw and measured by thermal and mechanical threshold of sensory pain (Fig. $1 A$; twoway ANOVA, time: $F_{(16,96)}=7.219, p<0.001$; CFA: $F_{(1,6)}=$ $111.9, p<0.001$; interaction: $\left.F_{(16,96)}=8.442, p<0.001\right)$. To determine pain-induced changes in opioid reward at different stages of opioid exposure, we assessed opioid reward with the CPP paradigm (Tzschentke, 2007), which allows studies on initial acquisition of reward-related behavior and its reacquisition (reinstatement) after re-exposure to opioids. In naive mice, three daily sessions of morphine conditioning induced CPP behavior in a dose-dependent manner (Fig. $1 B$; one-way ANOVA, $F_{(3,15)}=$ $23.08, p<0.001$ ). In mice with the pain condition ( $3 \mathrm{~d}$ post-CFA injection), a subthreshold dose of morphine $(0.1 \mathrm{mg} / \mathrm{kg}$, i.p. $)$, ineffective in control mice, induced significant CPP after three 
A

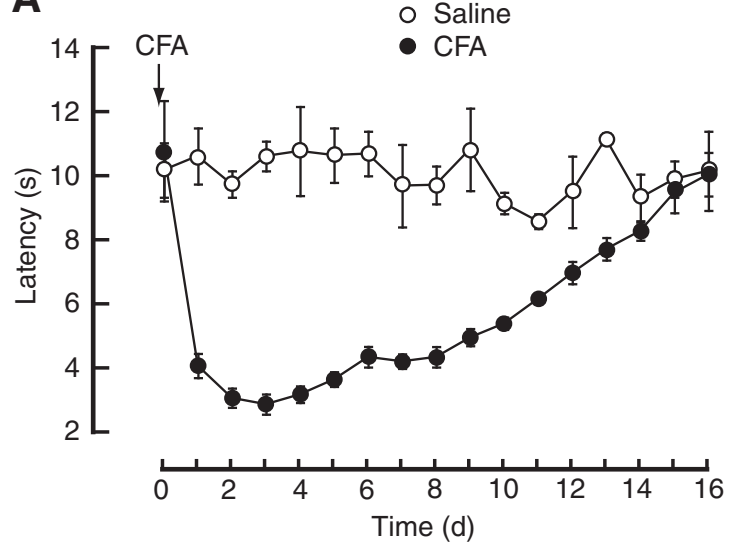

B

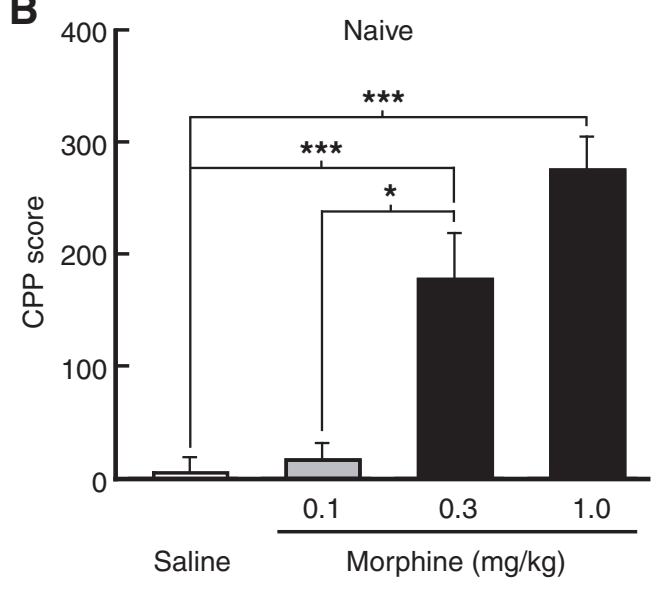

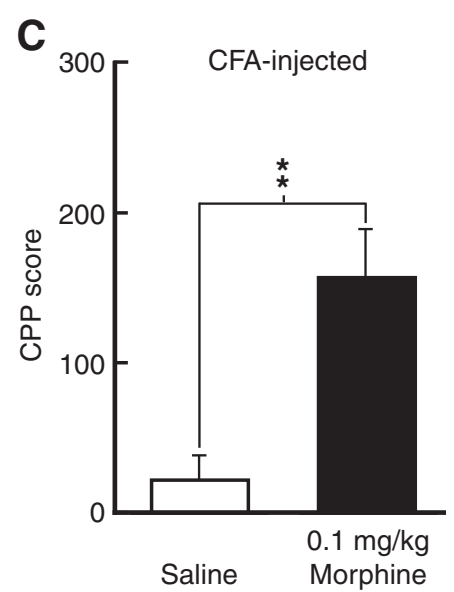

E

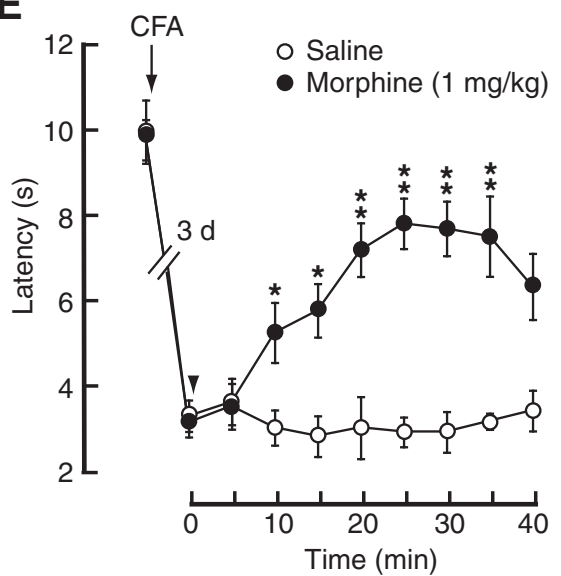

D Thermal
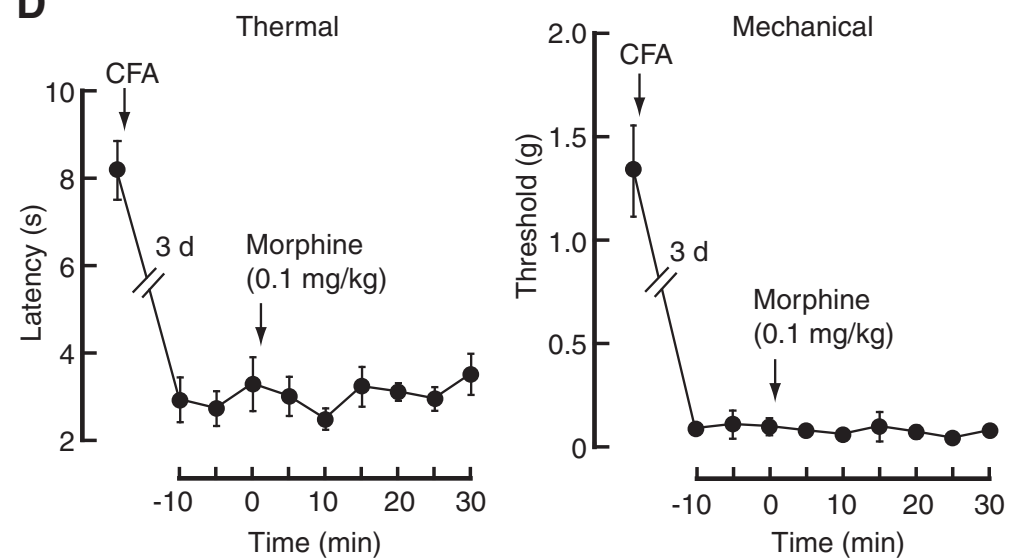

$\mathbf{F}$

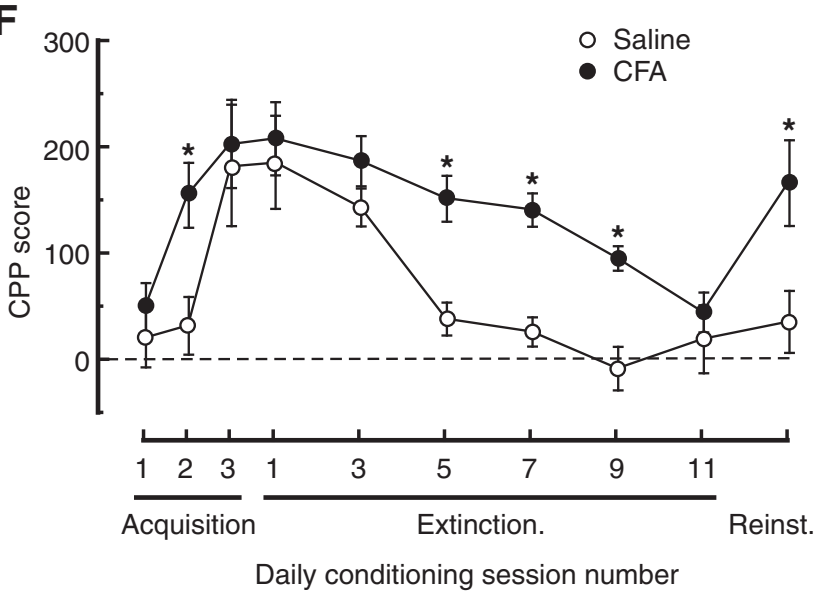

Figure 1. Acquisition of reward behavior is facilitated in pain conditions. $\boldsymbol{A}$, Time course for the development of persistent sensory pain induced by CFA and measured by the paw-withdrawal test ( $n=6$ mice each group). $\boldsymbol{B}$, Behavior of (PP in naive mice conditioned with saline or three doses of morphine ( $n=4-6$ mice each group). $\boldsymbol{C}$, CPP after conditioning with saline or a subthreshold dose of morphine in (FA-injected mice ( $n=8$ each group). $\boldsymbol{D}$, Effects of $0.1 \mathrm{mg} / \mathrm{kg}$ morphine on CFA-induced sensitization of thermal and mechanical pain. $\boldsymbol{E}$, Effects of $1 \mathrm{mg} / \mathrm{kg}$ morphine on CFA-induced sensitization of thermal pain. $\boldsymbol{F}$, Time course of (PP acquisition, extinction, and reinstatement (reinst.) in mice ( $n=6$ each group) injected with saline or CFA $3 \mathrm{~d}$ before the first conditioning session; ${ }^{*} p<0.05,{ }^{* *} p<0.01,{ }^{* * *} p<0.001$.

conditioning sessions (Fig. $1 C$; $t_{(1,14)}=3.641, p=0.0027$ ), suggesting increased response of CPP behavior to opioid reward under the pain condition. This low dose of morphine $(0.1 \mathrm{mg} / \mathrm{kg}$, i.p.) had no effect on CFA-induced sensory pain (Fig. 1D).

We then assessed this pain effect on CPP behavior at different stages of CPP acquisition, extinction, and reinstatement with a higher, analgesic dose of morphine at $1 \mathrm{mg} / \mathrm{kg}$ intraperitoneally (Fig. $1 E$; two-way ANOVA, time: $F_{(9,45)}=16.41, p<0.001$; mor- phine: $F_{(1,5)}=11.80, p=0.0185$; interaction: $F_{(9,45)}=3.847, p=$ 0.0011 ). During the initial acquisition period, mice with pain acquired CPP for morphine more rapidly than control mice. Specifically, control mice required a minimum of three daily morphine-conditioning sessions to acquire $\mathrm{CPP}$, but only two such sessions were sufficient in mice with pain (Fig. $1 F$; two-way ANOVA, time: $F_{(9,72)}=9.69, p<0.001$; CFA: $F_{(1,8)}=12.63, p=$ 0.0075; interaction: $\left.F_{(9,72)}=1.18, p=0.3201\right)$. However, after 
A
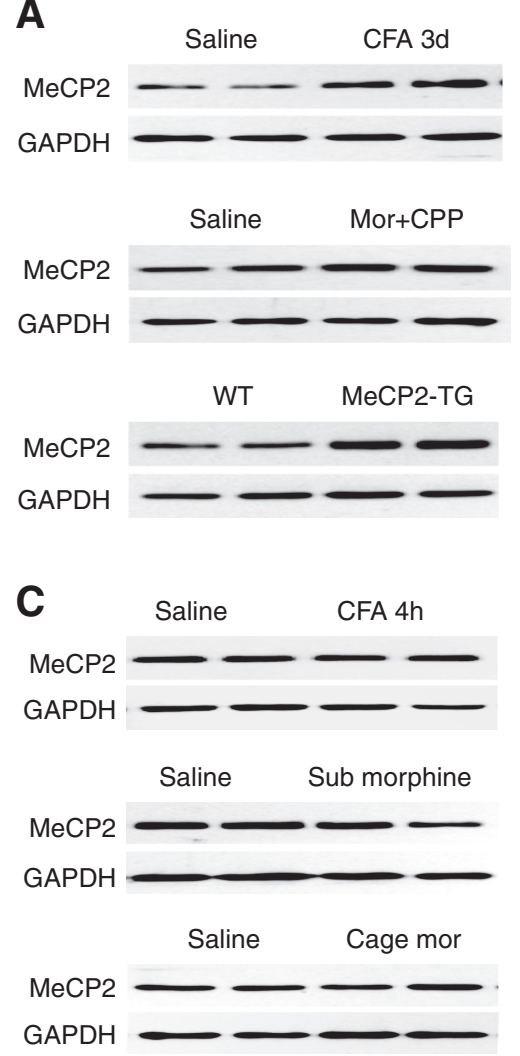

E

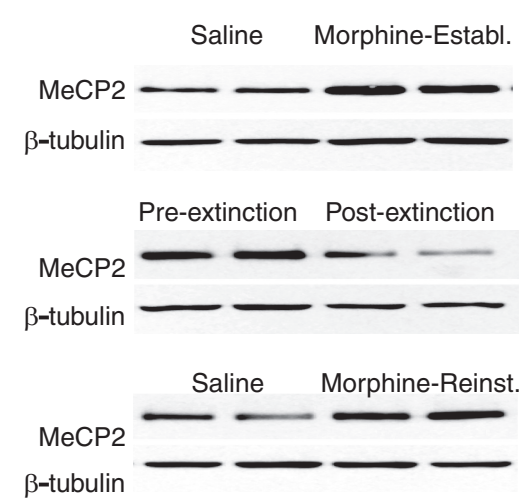

B
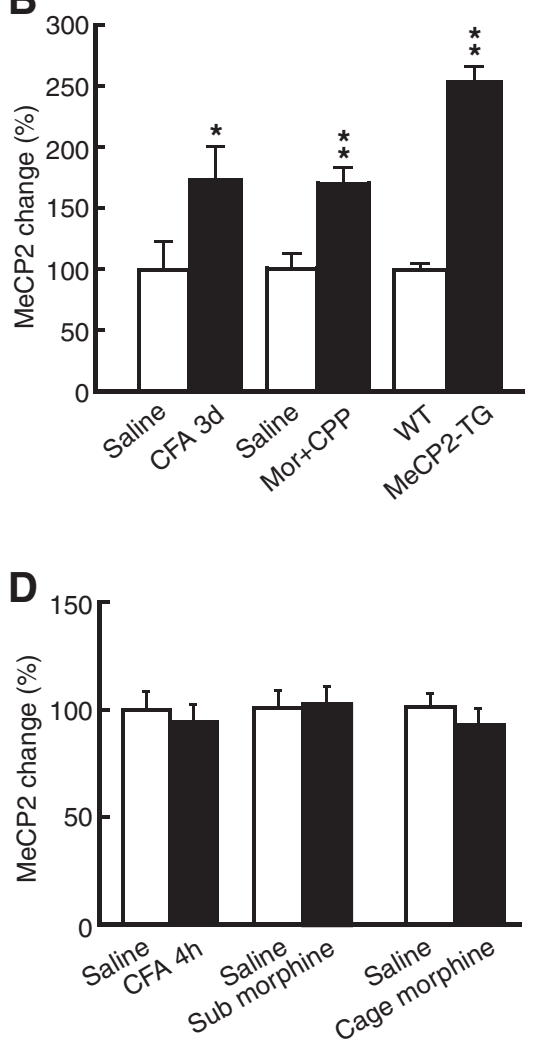

$\mathbf{F}$

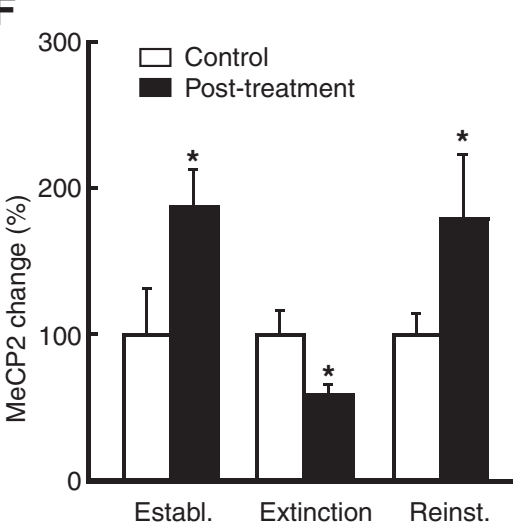

G

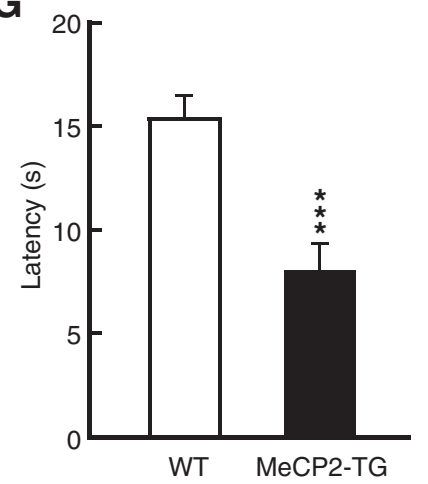

H

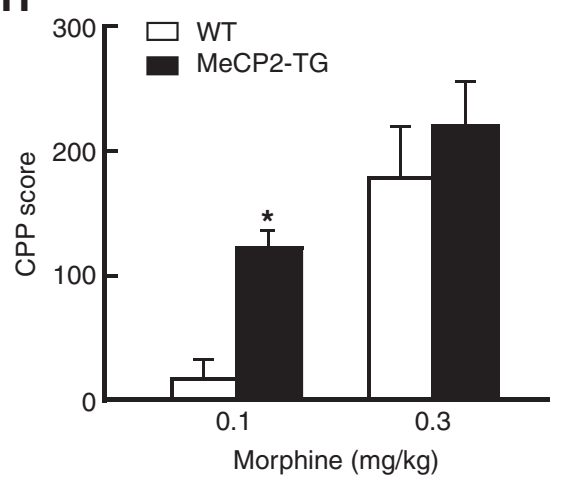

Figure 2. Persistent pain and morphine reward upregulate $M e(P 2$ in CeA. $\boldsymbol{A}, \boldsymbol{B}$, Representative Western blots $(\boldsymbol{A})$ and summarized results $(\boldsymbol{B})$ of MeCP2 protein in the CeA from mice with persistent pain (CFA $3 \mathrm{~d}, n=7$ mice per group), with $0.3 \mathrm{mg} / \mathrm{kg}$ morphine-induced CPP ( $n=4$ mice per group), and from MeCP2-overexpressing mice (MeCP2-TG, $n=8$ mice per group). $\boldsymbol{C}, \boldsymbol{D}$, Similar data of MeCP2 protein in the CeA from mice with acute pain (CFA 4h), mice conditioned by a subthreshold dose of morphine

the acquisition, both groups displayed CPP of similar amplitudes, suggesting that pain may mainly affect the sensitivity to acquiring CPP behavior. During CPP extinction induced by daily sessions of conditioning with saline only, CPP extinguished far less slowly in CFA-injected mice when compared with controls (Fig. $1 F$ ) while CFA-induced sensory pain was diminishing. After CPP extinction, the subthreshold dose of morphine $(0.1 \mathrm{mg} /$ $\mathrm{kg}$ ), ineffective in control mice, reinstated the CPP in CFA-injected mice (Fig. $1 F$ ) when CFA-induced sensory pain had fully recovered. These behavioral results suggest that the sensitivity to acquiring the opioid-induced preference behavior is increased under persistent pain conditions.

\section{MeCP2 is important for increased sensitivity to reward behavior}

Recent studies have shown that MeCP2 plays an important role in regulating drug reward-related motivational effects of cocaine and psychostimulants (Deng et al., 2010; Im et al., 2010). MeCP2 also has been implicated in modulation of pain behaviors in animals (Tochiki et al., 2012). Therefore, we examined the underlying molecular mechanisms for the pain effect, focusing on the role of $\mathrm{MeCP} 2$ in CeA regulation of pain and opioid reward. We found that MeCP2 expression in $\mathrm{CeA}$ was significantly increased in mice with persistent pain (Fig. $2 A, B ; t_{(1,12)}=2.266$, $p=0.0428)$, but not with acute pain ( $4 \mathrm{~h}$ post-CFA injection; Fig. 2C,D). MeCP2 also was increased in mice with morphine (0.3 mg/kg)-induced CPP (Fig. 2A,B; $\left.t_{(1,6)}=3.917, p=0.0078\right)$, but not in mice conditioned with a subthreshold morphine dose $(0.1 \mathrm{mg} / \mathrm{kg})$ without CPP (Fig. $2 C, D)$. Repeated home-cage injections of morphine $(0.3 \mathrm{mg} / \mathrm{kg})$ without conditioning treatment did not alter the MeCP2 expression (Fig. 2C,D). In addition, the $\mathrm{MeCP} 2$ expression was closely linked to the acquisition of CPP behavior, which was increased after initial CPP acquisition $\left(t_{(1,14)}=2.200, p=0.0451\right)$, decreased after CPP extinction $\left(t_{(1,14)}=2.417, p=\right.$

$\leftarrow$

$(0.1 \mathrm{mg} / \mathrm{kg}$, i.p.) with no CPP, and mice receiving injections of morphine $(0.3 \mathrm{mg} / \mathrm{kg}$, i.p.) in their home cages ( $n=4-7$ mice per group). $\boldsymbol{E}, \boldsymbol{F}$, Expression of CeA MeCP2 protein at the three CPP stages of establishment (establ.; after acquisition), extinction, and reinstatement (reinst.) in control mice and in (FAinjected mice ( $n=8$ mice per group). (PP was reinstated by $0.1 \mathrm{mg} / \mathrm{kg}$ morphine. G, Baseline pain threshold in WT $(n=5)$ and MeCP2-TG mice $(n=12) . H$, CPP behavior induced by two doses of morphine in WT $(n=5)$ and MeCP2-TG mice $(n=9)$. Mor, morphine. 
A

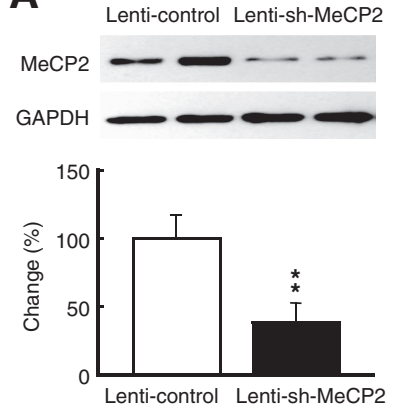

E

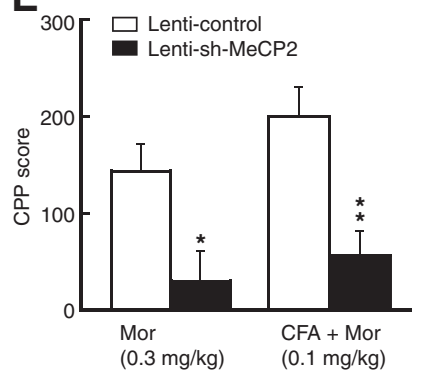

B

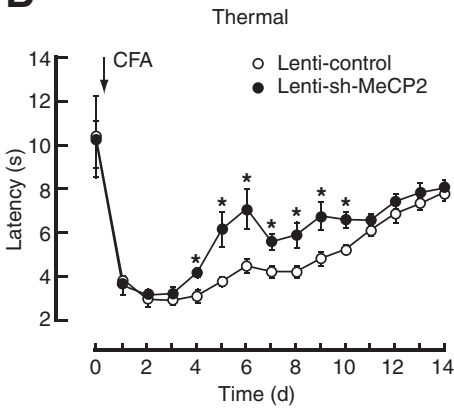

F

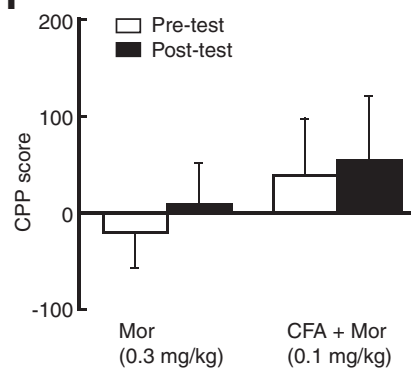

C
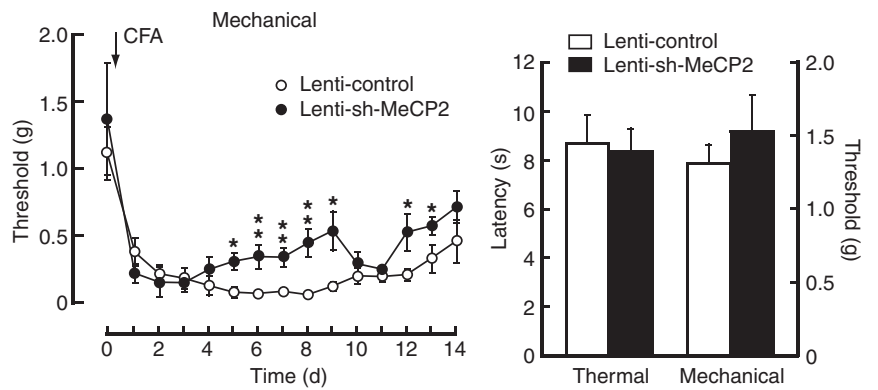

G

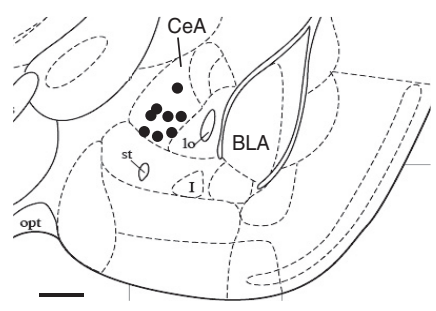

H

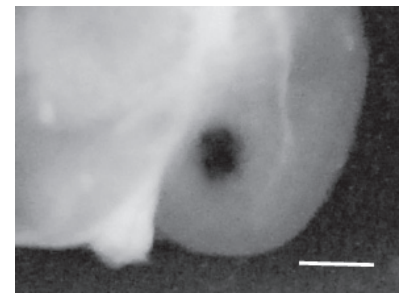

Figure 3. Knockdown of CeAMeCP 2 inhibits persistent pain and morphine reward. $\boldsymbol{A}$, Expression of CeA MeCP 2 protein in mice ( $n=4$ per group) after CeA infusion of a lentivirus vector expressing a short-hairpin interfering RNA against MeCP2 (lenti-sh-MeCP2) or a control empty lentivirus vector (lenti-control). $\boldsymbol{B}, \boldsymbol{C}$, Time course of CFA-induced changes in thermal ( $\boldsymbol{B}$ ) and mechanical ( $\boldsymbol{C}$ ) pain thresholds in mice with CeA infusion of lenti-sh-MeCP2 or control vector ( $n=5$ mice per group). $D$, Baseline pain thresholds in mice after CeA infusion of lenti-sh-MeCP2 or control vector ( $n=4$ mice per group). $\boldsymbol{E}$, CPP behaviors in naive mice conditioned with $0.3 \mathrm{mg} / \mathrm{kg}$ morphine and in CFA-injected mice conditioned with $0.1 \mathrm{mg} / \mathrm{kg} \mathrm{morphine}$ after CeA infusion of lenti-sh-MeCP2 or control vector ( $n=5$ mice per group). $\boldsymbol{F}$, Preference behaviors before (pretest) and after (post-test) morphine conditioning in mice with CeA infusion of lenti-sh-MeCP2, showing no significant CPP after $\mathrm{MeCP} 2$ knockdown in both groups $(n=5)$. $\boldsymbol{G}$, Schematic drawing showing representative positions of cannula tips within the CeA for the vector infusions. $\boldsymbol{H}$, Photomicrograph of a brain slice with similar infusion of a dye in CeA. Scale bars: $\boldsymbol{G}, 0.5 \mathrm{~mm} ; \boldsymbol{H}, 1 \mathrm{~mm}$.

$0.0299)$, and increased again after CPP reinstatement $\left(t_{(1,14)}=\right.$ 2.300, $p=0.0373$ ) in CFA-injected mice (Fig. 2E,F). Using the transgenic line of MeCP2-overexpressing mice (MeCP2-TG; Chahrour et al., 2008), we found that the MeCP2 level was 2.5fold higher in the CeA of MeCP2-TG mice compared with WT controls (Fig. $2 A, B ; t_{(1,14)}=3.719, p=0.0023$ ). Consistently, MeCP2-TG mice displayed sensitized pain behavior with lower baseline pain threshold (Fig. $2 G ; t_{(1,22)}=6.496, p<0.001$ ) and their sensitivity to morphine-induced CPP was also increased (Fig. $2 H$; two-way ANOVA; MeCP2-TG: $F_{(1,20)}=8.374, p=$ 0.0090; morphine dose: $F_{(1,20)}=26.24, p<0.0001$; interaction: $\left.F_{(1,20)}=1.578, p=0.2235\right)$, similar to the CFA-injected mice. Noticeably, the small increase in the magnitude of CPP induced by the higher morphine dose $(0.3 \mathrm{mg} / \mathrm{kg})$ in MeCP2-TG mice was not statistically significant (Fig. $2 H$ ), indicating a possibility that the sensitivity increase for acquired CPP is masked by increasing doses of morphine.

To further determine the MeCP2 role, we used a recently described lentivirus vector expressing a short-hairpin interfering RNA against MeCP2 (lenti-sh-MeCP2; Im et al., 2010) to knockdown $\mathrm{CeA} \mathrm{MeCP} 2$ by CeA infusion of the vector. Lenti-sh-MeCP2 reduced CeA MeCP2 level by $\sim 60 \%$ (Fig. $3 A ; t_{(1,6)}=3.810, p=$ $0.0089)$. CFA-induced pain sensitization was significantly inhibited in mice with CeA infusions of lenti-sh-MeCP2 when compared with control mice receiving $\mathrm{CeA}$ infusions of a control empty lentivirus vector (lenti-control; Fig. 3B, $C$; two-way ANOVA; Thermal, time: $F_{(14,112)}=31.61, p<0.001$; sh-MeCP2: $F_{(1,8)}=13.20, p=0.0142$; interaction: $F_{(14,112)}=1.73, p=$ 0.0592. Mechanical, time: $F_{(14,112)}=21.58, p<0.001$; shMeCP2: $F_{(1,8)}=5.96, p=0.0405$; interaction: $F_{(14,112)}=2.01$, $p=0.023)$. CeA infusions of lenti-sh-MeCP2 had no effect on baseline pain threshold in WT mice (Fig. 3D). Lenti-sh-MeCP2mediated knockdown of CeA MeCP2 greatly inhibited the reward response to morphine-induced CPP in naive mice $\left(t_{(1,8)}=\right.$ $3.110, p=0.0144)$; and it also reversed the sensitized response to subthreshold morphine-induced CPP in CFA-injected mice $\left(t_{(1,8)}=3.706, p=0.006\right.$; Fig. $\left.3 E, F\right)$. Representative positions of the cannula tips within the CeA for effective vector infusions are shown in Figure $3 G$ and photomicrograph of a brain slice with $\mathrm{CeA}$ infusion of a dye is illustrated in Figure $3 \mathrm{H}$. Together, these results provide several lines of evidence suggesting that amygdalar MeCP2 regulates behavioral responses to pain and opioid reward, and is important for the increased CPP sensitivity in pain conditions.

\section{$\mathrm{MeCP} 2$ represses $\mathrm{G} 9 \mathrm{a}$}

Next, we determined the targets of MeCP2 in the pain effect by examining changes in the expression of possible candidate proteins, focusing on those that are related to MeCP2-mediated gene repression and are involved in neurological diseases from the list of genes that have been shown to be regulated by MeCP2 (Chahrour et al., 2008). Consistent with the previous report (Chahrour et al., 2008), we found that a range of proteins known to be involved in pain and drug-induced neuroplasticity (Pan et al., 1997; Basbaum et al., 2009; Robison and Nestler, 2011) were in fact upregulated (not repressed) in the CeA of MeCP2overexpressing mice (Fig. $4 A$; KCC2: $t_{(1,12)}=3.899, p=0.0021$; NGF: $t_{(1,6)}=2.895, p=0.0275$; BDNF: $t_{(1,6)}=4.426, p=$ $0.0044)$. Of note is the unchanged expression of repressor element 1-silencing transcription factor (REST), another general neuronal transcriptional repressor (Ooi and Wood, 2007). Among those proteins that were downregulated by MeCP2 over- 

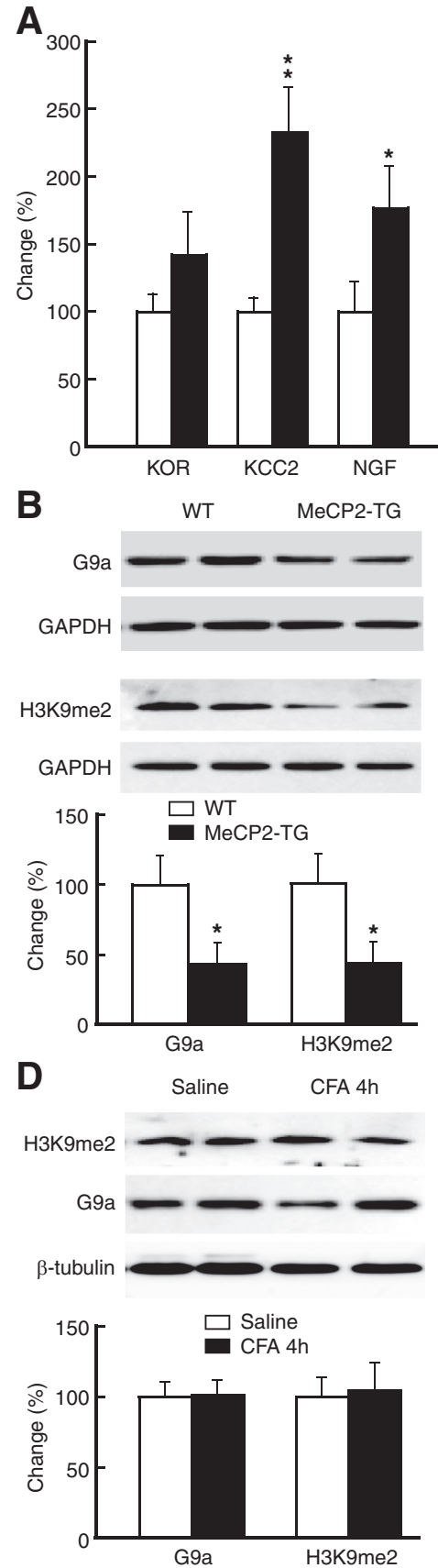

$\mathbf{F}$
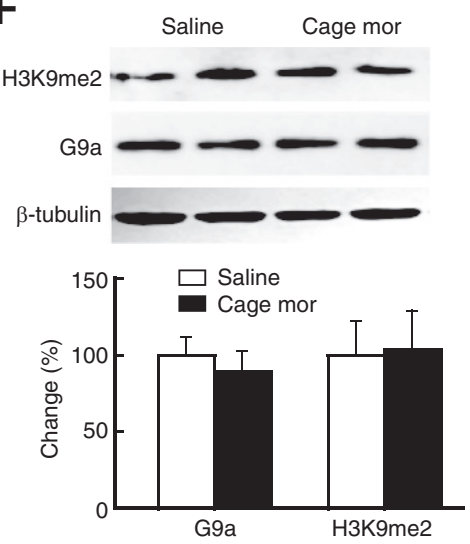

$\square$ WT

MeCP2-TG

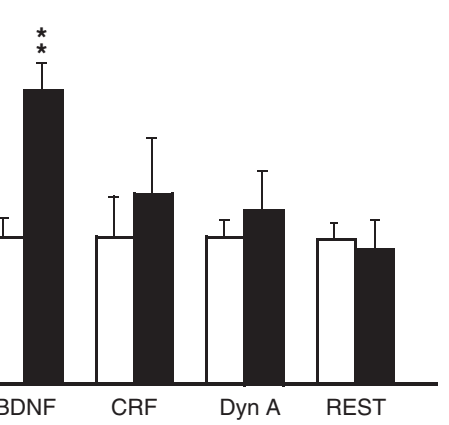

C
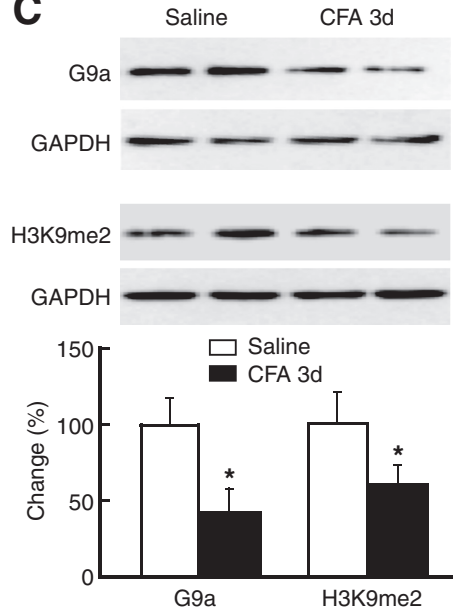

E
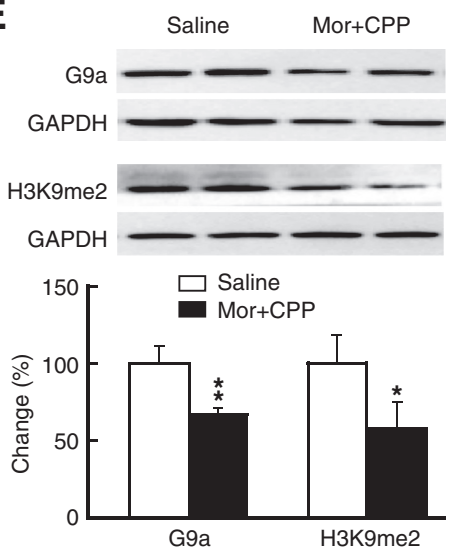

G

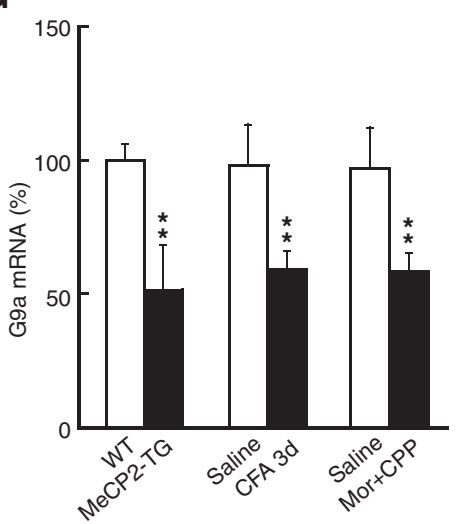

Figure 4. MeCP2 represses $\mathrm{G} 9$ a expression. $A$, Expression of selected proteins analyzed by Western blotting in the CeA from WT and MeCP2-TG mice ( $n=4-7$ mice per group). KOR, $\kappa$ opioid receptor; $\mathrm{KCC} 2, \mathrm{~K}^{+} / \mathrm{C}^{-}$cotransporter; NGF, nerve growth factor;

expression, we found that the expression of the histone dimethyltransferase G9a showed a profound decrease $(>50 \%)$ in the CeA of MeCP2-TG mice (Fig. $4 B$; $\left.t_{(1,14)}=2.442, p=0.0285\right)$. G9a specifically catalyzes the dimethylation of Histone 3 at lysine 9 (H3K9me2), an epigenetic mark for transcriptional repression, and plays an important role in MeCP2-related mechanism of gene repression in neurological diseases (Li et al., 2007; Maze et al., 2010; Robison and Nestler, 2011). This indicates that MeCP2 may regulate pain responses and morphine reward through transcriptional repression of G9a in CeA. Consistently, protein level of G9a in CeA was significantly reduced in mice with persistent pain (Fig. $4 C ; t_{(1,8)}=2.380, p=0.0445$ ), but not with acute pain (Fig. 4D). The G9a protein level was also reduced in mice displaying morphine-induced CPP (Fig. $4 E$; $\left.t_{(1,12)}=3.334, p=0.0059\right)$, but not in mice receiving morphine injections in their home-cages (Fig. 4F). Levels of H3K9me2 in CeA were changed accordingly along with G9a protein (Fig. $4 B-F$; MeCP2-TG: $t_{(1,14)}=2.785, p=0.0146$; CFA: $t_{(1,10)}=2.533, p=0.0297$; morphine: $\left.t_{(1,7)}=2.880, p=0.0237\right)$. Corresponding changes also were found at G9a mRNA levels (Fig. 4G; MeCP2-TG: $t_{(1,14)}$ $=3.379, p=0.0045$; CFA: $t_{(1,14)}=3.258$, $p=0.0057$; morphine: $t_{(1,14)}=3.276, p=$ 0.0055).

Further supporting a repressive role of MeCP2 on G9a expression, lenti-sh$\mathrm{MeCP} 2$ knockdown of MeCP2 increased levels of G9a protein $\left(t_{(1,14)}=2.312, p=\right.$ $0.0393), \mathrm{H} 3 \mathrm{~K} 9 \mathrm{me} 2$ marks $\left(t_{(1,14)}=3.097\right.$, $p=0.0079)$, and G9a mRNA $\left(t_{(1,14)}=\right.$ $3.123, p=0.0088$ ) in CeA (Fig. $5 A, B)$. To determine whether $\mathrm{MeCP} 2$ directly regulated $G 9 a$ transcription, we examined the physical association of MeCP2 with the G9a promoter in CeA tissues by ChIP assays. Using primers spanning the region from $-100 \mathrm{bp}$ to $-3 \mathrm{~kb}$ upstream of the transcription start site (TSS) of $G 9 a$, we found selective enrichment of MeCP2 oc-

CRF, corticotropin-releasing factor; Dyn A, Dynorphin A. $\boldsymbol{B}-\boldsymbol{F}$, Levels of $\mathrm{G} 9$ a protein and $\mathrm{H} 3 \mathrm{~K} 9 \mathrm{me} 2$ in the CeA from MeCP2-TG mice $(n=8$ per group; $\boldsymbol{B})$, from mice with persistent pain $(n=4-6$ per group; $C$ ), from mice with acute pain $(n=4$ per group; $\boldsymbol{D})$, from mice with morphine-induced CPP $(n=4-7$ per group; $\boldsymbol{E}$ ), and from mice receiving injections of morphine $(0.3 \mathrm{mg} / \mathrm{kg}$, i.p.) in their home cages $(n=4-7$ per group; $\boldsymbol{F})$. $G$, Levels of G9a mRNA determined by quantitative RT-PCR in the CeA from mice with MeCP2 overexpression, with persistent pain, or with morphine (Mor)-induced CPP ( $n=6-8$ per group). 
cupancy in the proximal promoter regions upstream of TSS in mouse CeA tissues, and this binding was markedly reduced in mice with virus-mediated knockdown of MeCP2 in CeA (Fig. $5 C$; $\left.t_{(1,14)}=3.670, p=0.0025\right)$. In the $G 9 a$ promoter region of -316 to $-251 \mathrm{bp}$ where MeCP2 binding was decreased by local MeCP2 knockdown, ChIP analysis showed that MeCP2 occupancy was significantly increased in the CeA of mice under behavioral conditions where $\mathrm{MeCP} 2$ expression was increased (Fig. $2 B$ ), including mice with $\mathrm{MeCP} 2$ overexpression $\left(t_{(1,6)}=2.721, p=0.0346\right)$, mice with persistent pain $\left(t_{(1,12)}=3.164, p=\right.$ $0.0082)$, and mice with morphineinduced CPP $\left(t_{(1,6)}=3.318, p=0.016\right.$; Fig. $5 D)$. Conversely, MeCP2 knockdown decreased the MeCP2 occupancy on the $G 9 a$ promoter (Fig. $5 D ; t_{(1,12)}=3.482$, $p=0.0045)$. These findings suggest a direct $\mathrm{MeCP} 2$ repression of $G 9 a$ transcription in CeA.

\section{G9a knockdown increases pain and morphine reward}

Based on the above findings, it appears that direct repression of G9a by MeCP2 in CeA contributes to the pain-increased sensitivity to morphine-induced CPP. To test this hypothesis, we examined pain effects on behavior of opioid reward after knockdown of G9a in CeA, using an AAV-

EF1a-mCherry-IRES-WGA-Cre (AAV-Cre) vector (Fig. 6A). Infusion of AAV-Cre into the CeA of $\mathrm{G} 9 \mathrm{a}^{\mathrm{f} / \mathrm{fl}}$ mice significantly reduced the levels of G9a protein $\left(t_{(1,10)}=6.889, p<0.0001\right)$ and H3K9me2 $\left(t_{(1,10)}=3.370, p=0.0071\right)$, but not G9a-like protein (GLP) and EZH2, two other repressive histone methyltransferases (Fig. $6 B, C$ ). Supporting a localized effect, G9a expression in the basolateral amygdala (BLA) was not affected by the transgene (Fig. $6 B, C$ ). We then determined the behavioral effect of this G9a knockdown and found that AAV-Cre-injected G9a $\mathrm{a}^{\mathrm{fl} / \mathrm{fl}}$ mice displayed sensitized pain response $\left(t_{(1,12)}=2.243, p=\right.$ $0.0446)$ and increased sensitivity to morphine-induced CPP $\left(t_{(1,10)}=2.503, p=0.0313\right)$ when compared with AAV-GFPinjected control G9a ${ }^{\mathrm{fl} / \mathrm{fl}}$ mice (Fig. $6 D$ )-findings similar to those observed in MeCP2-overexpressing mice (Fig. 2G,H).

\section{G9a represses BDNF}

It has been shown that MeCP2 controls BDNF expression with positive correlation in expression and through homeostatic interaction with microRNA-212 (Sun and Wu, 2006; Im et al., 2010), but the epigenetic mechanism by which MeCP2 upregulates BDNF expression is unclear. Considering our current findings and previous reports that BDNF has promoting roles in both chronic pain and drug addiction (Pezet and McMahon, 2006; Pickens et al., 2011), we hypothesized that MeCP2 may regulate BDNF indirectly through G9a in CeA and BDNF may be an important target gene in the regulating cascade of MeCP2-G9a. Consistent with this hypothesis, we found that BDNF protein level was increased in the CeA of mice with persistent pain or morphine-induced CPP (Fig. 7 A,B; CFA: $t_{(1,19)}=2.208, p=$

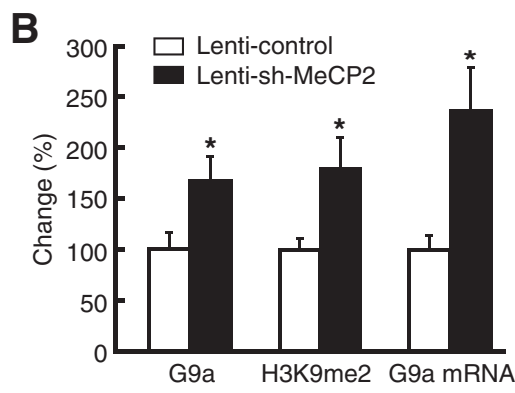

D

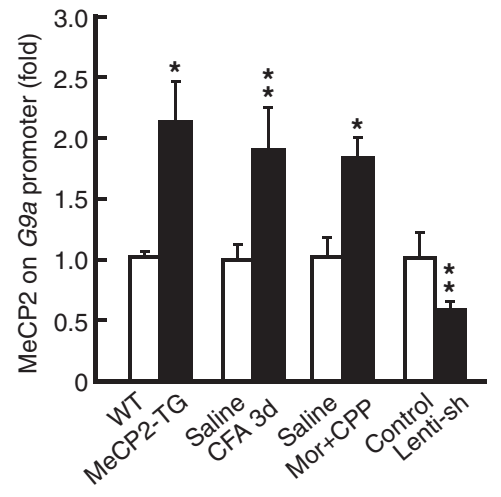

0.0397; morphine: $\left.t_{(1,13)}=2.744, p=0.0167\right)$. In contrast to previous reports on direct $\mathrm{MeCP} 2$ repression of $B d n f$ transcription in cultured cortical cells (Chen et al., 2003; Martinowich et al., 2003), we found that BDNF was upregulated in the CeA of $\mathrm{MeCP} 2$-overexpressing mice and was downregulated by $\mathrm{MeCP} 2$ knockdown in vivo (Fig. 7 A, B; MeCP2-TG: $t_{(1,12)}=5.753, p=$ 0.0001; Lenti-sh-MeCP2: $\left.t_{(1,6)}=3.372, p=0.015\right)$. However, $\mathrm{MeCP} 2$ occupancy at various $B d n f$ promoters in CeA was unchanged in mice with persistent pain (Fig. $7 C$ ), indicating an indirect interaction of $\mathrm{MeCP} 2$ and $B d n f$. In contrast, G9a occupancy on the $B d n f$ axon II and IV promoters was reduced in mice with persistent pain (Fig. $7 D$; promoter II: $t_{(1,6)}=3.145, p=$ 0.0199 ; promoter IV: $\left.t_{(1,6)}=3.130, p=0.0203\right)$. Additionally, both the G9a binding of $B d n f$ promoter II and H3K9me2 levels were reduced in mice under conditions of increased MeCP2 expression by persistent pain (G9a: $t_{(1,6)}=3.130, p=0.0203$; H3K9me2: $\left.t_{(1,6)}=3.847, p=0.0085\right)$, by morphine-induced CPP (G9a: $t_{(1,6)}=2.639, p=0.0386$; H3K9me2: $t_{(1,6)}=3.268$, $p=0.0171)$, and by MeCP2 overexpression (G9a: $t_{(1,6)}=4.320$, $p=0.005$; H3K9me2: $\left.t_{(1,6)}=4.363, p=0.0048\right)$, but were increased by MeCP2 knockdown (G9a: $t_{(1,6)}=2.465, p=0.0488$; H3K9me2: $t_{(1,6)}=3.128, p=0.0204$ ) in CeA (Fig. 7E). As shown in Figure 7F, the G9a inhibitor UNC0224 or the G9a/GLP inhibitor BIX01294 infused into CeA also reduced the H3K9me2 level at the $B d n f$ promoter $\left(\mathrm{UNC0224:} t_{(1,8)}=2.850, p=0.0215\right.$; BIX01294: $\left.t_{(1,10)}=3.069, p=0.0119\right)$ and increased BDNF protein level (UNC0224: $t_{(1,6)}=4.052, p=0.0067$; BIX01294: $t_{(1,6)}$ $=4.052, p=0.0067)$. These data support a direct G9a repression 
A
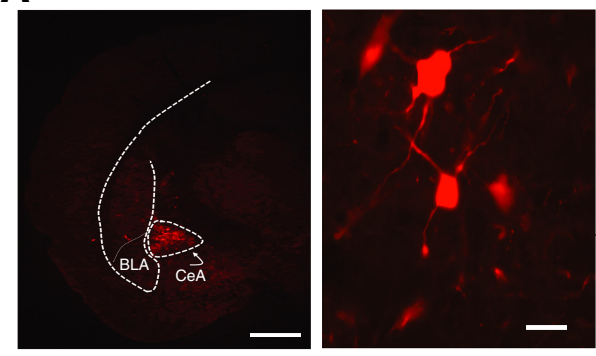

B
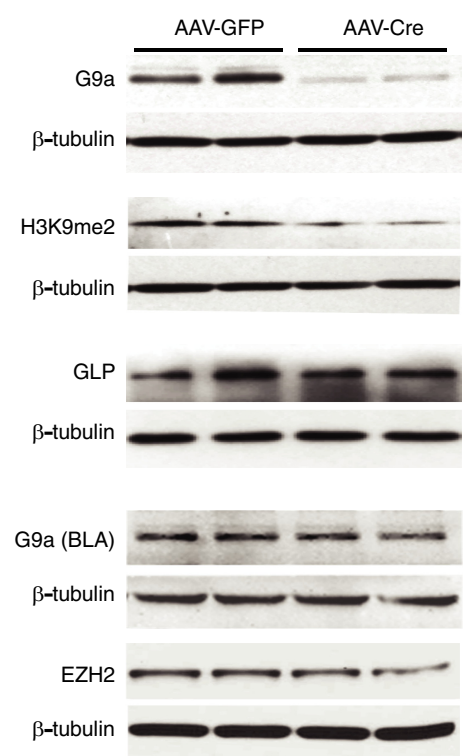

C

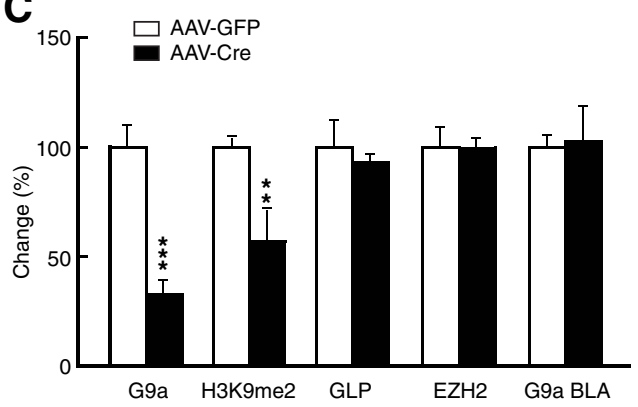

D

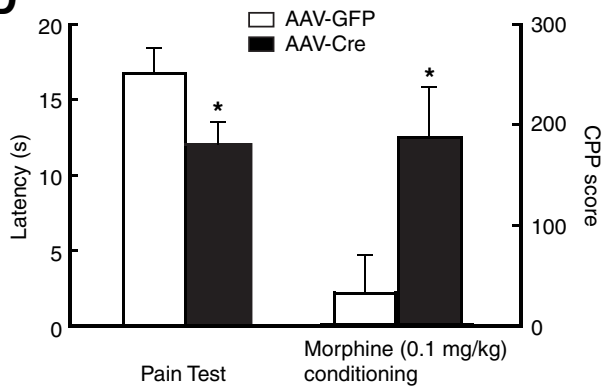

Figure 6. Knockdown of CeA G9a facilitates behavior of morphine reward. $A$, Representative images of expression of an AAV-Cre vector infused in the CeA (left) and in the CeA neurons (right) from a $\mathrm{G}_{\mathrm{a}} \mathrm{a}^{\mathrm{f} / \mathrm{f}}$ mouse. Scale bars: Left, $500 \mu \mathrm{m}$; right, $15 \mu \mathrm{m} . \boldsymbol{B}, \boldsymbol{C}$, Western blots $(\boldsymbol{B})$ and summarized data ( $C$ ) of CeA levels of G9a, H3K9me2, GLP, and EZH2 ( $n=5-6$ mice per group), and G9a in the BLA ( $n=4$ mice per group) in $\mathrm{Gga}^{\mathrm{f} / / \mathrm{fl}}$ mice after CeA infusion of AAV-GFP (control) or AAV-Cre. D, Pain thresholds and (PP behaviors induced by a subthreshold dose of morphine $(0.1 \mathrm{mg} / \mathrm{kg})$ in the AAVGFP-treated and AAV-Cre-treated G9a ${ }^{\text {fl/f }}$ mice $(n=6-8$ mice per group). of $B d n f$ expression and suggest that $\mathrm{MeCP} 2$ may upregulate BDNF by repressing G9a expression in CeA.

We then examined the roles of G9a and BDNF in behaviors of pain and morphine reward in mice in vivo. In contrast to the pain-inhibiting effect of MeCP2 knockdown (Fig. 3B,C), CeAinfusion of the G9a inhibitors enhanced CFA-induced pain response (Fig. $8 A$, two-way ANOVA; time: $F_{(6,78)}=62.87, p<$ 0.001 ; inhibitor: $F_{(2,13)}=3.753 ; p=0.0517$; interaction: $F_{(12,78)}$ $=2.317, p=0.0137)$. Mimicking the pain effect of increased response to morphine-induced CPP (Fig. 1C), this G9a inhibition also rendered the subthreshold dose of morphine $(0.1 \mathrm{mg} /$ $\mathrm{kg}$ ) effective in inducing CPP (Fig. $8 B$; UNC0224: $t_{(1,9)}=2.994$, $p=0.0151$; BIX01294: $\left.t_{(1,9)}=3.177, p=0.0112\right)$. These findings suggest that G9a inhibition augments pain response and increases response in morphine-induced CPP behavior, similar to conditions of persistent pain where $\mathrm{MeCP} 2$ expression is upregulated. Consistent with the effect of G9a inhibition, CeA infusion of BDNF, whose transcription was repressed by G9a, promoted responses to pain and morphine reward (Fig. $8 D$; two-way ANOVA; time: $F_{(6,108)}=8.794, p=0.0001$; BDNF: $F_{(1,18)}=$ $1.543, p=0.2301$; interaction: $F_{(6,108)}=9.834, p=0.0001$; Figure $8 E$; morphine $\left.0.1 \mathrm{mg} / \mathrm{kg}, t_{(1,9)}=6.258, p=0.0001\right)$. Importantly, CeA-applied BDNF rescued CPP by overcoming the inhibition of morphine CPP induced by MeCP2 knockdown (Fig. $8 E ; t_{(1,9)}=$ $3.610, p=0.0057)$. Supporting the pain-promoting and rewardfacilitating effects of CeA BDNF, blocking BDNF signaling by CeA infusion of TrkB-IgG inhibited CFA-induced pain sensitization (Fig. 8F; two-way ANOVA; time: $F_{(8,112)}=70.62, p<$ 0.0001; TrkB-IgG: $F_{(1,14)}=13.45, p=0.0025$; interaction: $F_{(8,112)}$ $=7.396, p=0.0001)$; it also reduced morphine-induced CPP in WT mice (Fig. $8 G ; t_{(1,8)}=4.220, p=0.0029$ ). CeA-infused TrkBIgG also blocked the increased response in CPP induced by persistent pain $\left(t_{(1,9)}=2.748, p=0.0226\right)$ and by $\mathrm{MeCP} 2$ overexpression $\left(t_{(1,13)}=5.192, p=0.0002\right.$; Fig. $\left.8 G\right)$. Thus, it appears that G9a binds to $B d n f$ promoters and represses $B d n f$ expression, and G9a inhibition and activation of BDNF signaling in CeA have the same effect of pain augmentation and reward facilitation. Finally, CPP behavior might be confounded by a pain-induced effect on locomotor activity. In an open field test, we found that mice in saline- and CFA-injected groups displayed similar total distance traveled during the test, and there was also no significant difference in total distance traveled before and after CFA injection (two-way ANOVA; time: $F_{(1,10)}=1.791, p=$ 0.2104; CFA: $F_{(1,10)}=0.7360, p=0.4110$; interaction: $F_{(1,10)}=$ $1.423, p=0.2604$; Figure $8 I$ ). These data indicate little impact of the pain condition on general locomotor activity of the animals, which is consistent with a previous report under similar pain conditions in mice (Urban et al., 2011).

\section{Discussion}

The present study has presented several lines of molecular evidence suggesting that G9a is a direct transcriptional target of $\mathrm{MeCP} 2$ in the regulating cascade of MeCP2-G9a-BDNF in CeA regulation of pain and morphine reward. This convergence of regulating mechanisms on common epigenetic regulators may provide a molecular base for understanding functional interactions between pain responses and rewarding effects of opioids through emotion regulations by CeA. Our findings indicate that priming of this shared mechanism in CeA may contribute to increased response in behavioral preference for opioids under pain conditions.

The molecular function of $\mathrm{MeCP} 2$ as a transcriptional regulator has attracted much research attention in recent years due to its 


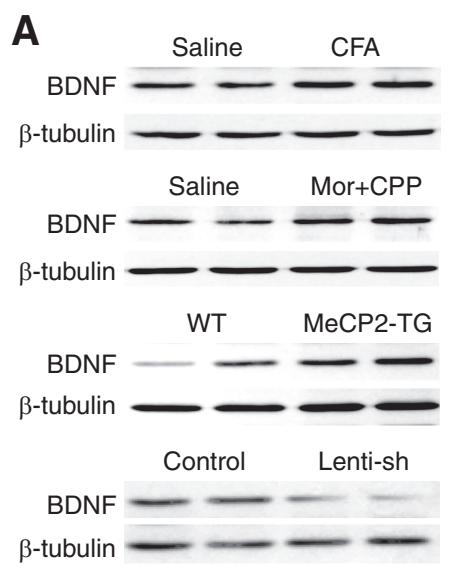

E

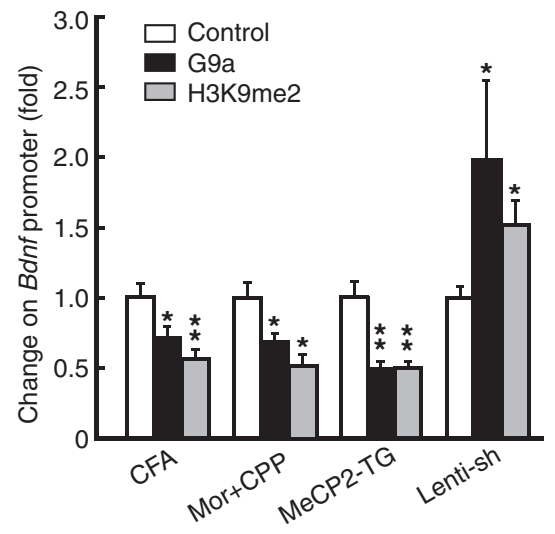

B

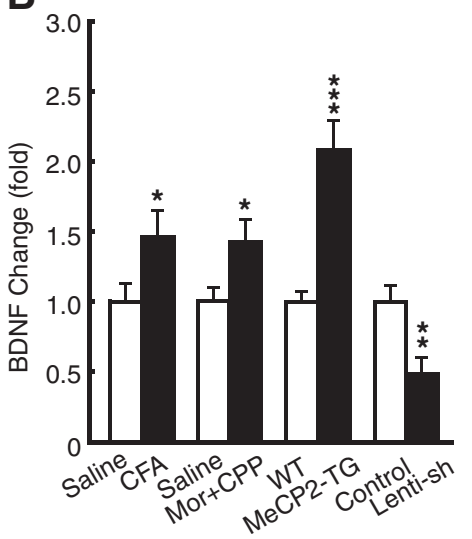

C

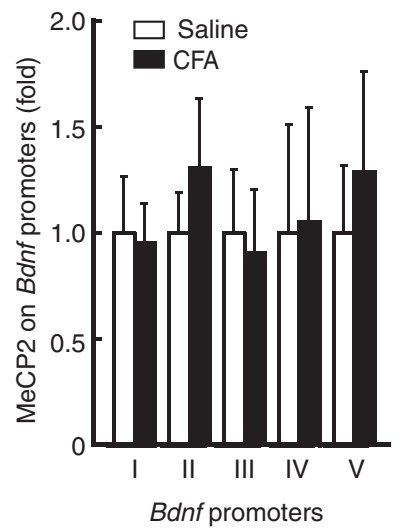

D

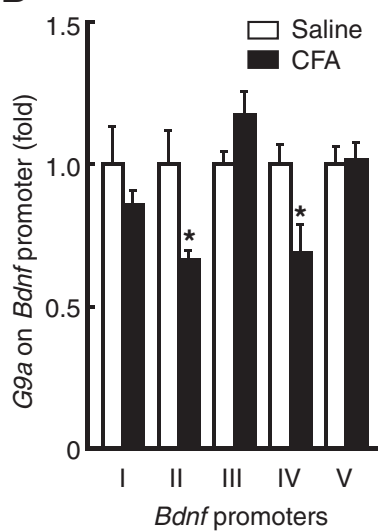

F

Figure 7. G9a represses BDNF. $\boldsymbol{A}, \boldsymbol{B}$, Western blot $(\boldsymbol{A})$ and summarized data $(\boldsymbol{B})$ of CeA BDNF protein in mice with CFA-induced pain, with morphine-induced CPP, with overexpression of CeA $\mathrm{MeCP} 2$, and with CeA infusion of lenti-sh-MeCP2 vector ( $n=4-12$ mice per group). $\boldsymbol{C}, \boldsymbol{D}$, Levels of MeCP2 (C) and G9a (D) on different $B d n f$ promoters in saline- and CFA-injected mice ( $n=4-8$ mice per group). $\boldsymbol{E}$, Levels of $\mathrm{G} 9 \mathrm{a}$ ( $n=4-8$ mice per group) and H3K9me2 ( $n=4-6$ mice per group) on the Bdnf promoter in mice groups as in $\boldsymbol{B}$. $\boldsymbol{F}$, CeA levels of $\mathrm{H} 3 \mathrm{~K} 9 \mathrm{me} 2$ and $\mathrm{BDNF}$ protein in mice ( $n=4-6$ per group) treated by CeA infusion of the G9a inhibitors. Mor, morphine.

important roles in many neurological diseases (Samaco and Neul, 2011). MeCP2 has been prevailingly regarded as a general repressor by associating with transcriptional corepressors to inhibit gene transcription (Lewis et al., 1992; Bienvenu and Chelly, 2006). However, this original view has been extended by recent evidence suggesting that $\mathrm{MeCP} 2$ also functions as a transcriptional activator. In addition to earlier evidence that is inconsistent with an exclusive gene-silencing role of MeCP2 (Chang et al., 2006; Yasui et al., 2007), the study by Chahrour et al. (2008), using mice lacking or overexpressing $\mathrm{MeCP} 2$, has provided compelling evidence that the majority of hypothalamus genes are in fact activated by $\mathrm{MeCP} 2$, and MeCP2 binds to the promoters of the transcriptional activator cAMP response element binding protein (CREB) on selected genes. This presents a model of direct transcriptional activation by $\mathrm{MeCP} 2$. In contrast, the current study in CeA suggests a model of indirect transcriptional activation of BDNF by MeCP2 through de-repression (i.e., repression of the repressor G9a), and provides molecular evidence for the direct interactions of MeCP2-G9a and G9a-BDNF. It is interesting to note that such an indirect $\mathrm{MeCP} 2$ activation of target genes appears lacking in hypothalamus, as no repressor was found repressed by MeCP2 as previously described (Chahrour et al., 2008). The present study is in line with previous reports (Chang et al., 2006; Chahrour et al., 2008) in that MeCP2 activates Bdnf transcription in the brain, but direct MeCP2 binding to $B d n f$ promoters has been reported to date only in cultured cortical neurons in vitro where $\mathrm{MeCP} 2$ represses Bdnf expression (Chen et al., 2003; Martinowich et al., 2003). Another reported mechanism of indirect $\mathrm{MeCP} 2$ regulation of $\mathrm{BDNF}$ is mediated by homeostatic interactions of MeCP2 with microRNA-212 in striatum (Im et al., 2010). Thus, it appears that MeCP2 may repress or activate transcriptional activity of target genes either directly or indirectly through corepressors in different brain regions.

Recent studies have demonstrated critical roles of $\mathrm{MeCP} 2$ and G9a in a number of neuropsychiatric disorders and particularly in drug addiction. MeCP2 in striatum and nucleus accumbens (NAc) was found to mediate cocaine intake and behavioral response to psychostimulants (Deng et al., 2010; Im et al., 2010). G9a in NAc was recently reported to inhibit preference behavior for both cocaine and morphine (Maze et al., 2010; Sun et al., 2012). Repressive MeCP2 control of BDNF was characterized in BDNF-promoted behavior of cocaine intake (Im et al., 2010; Sadri-Vakili et al., 2010). Our findings in this study of CeA are in general agreement with these reports on reward-promoting roles of MeCP2 and BDNF, and further suggest repressive interactions between MeCP2 and G9a for control of BDNF expression in the preference behavior of opioid reward.

Evidence for roles of epigenetic regulators in the mechanisms of pain behaviors is just emerging (Denk and McMahon, 2012). Expression of MeCP2 in spinal cord was recently found altered under pain conditions (Tochiki et al., 2012; Kynast et al., 2013). A 
A

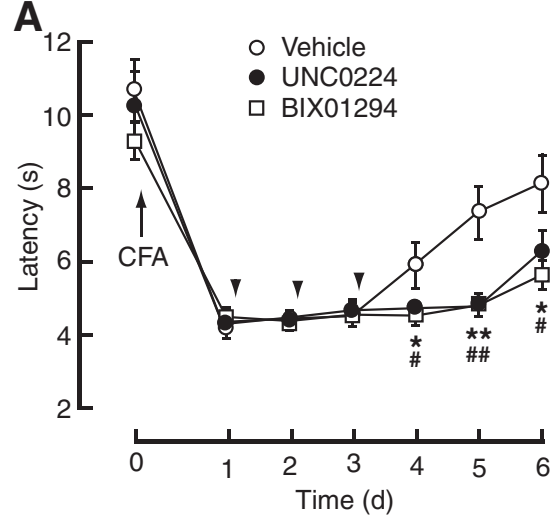

D

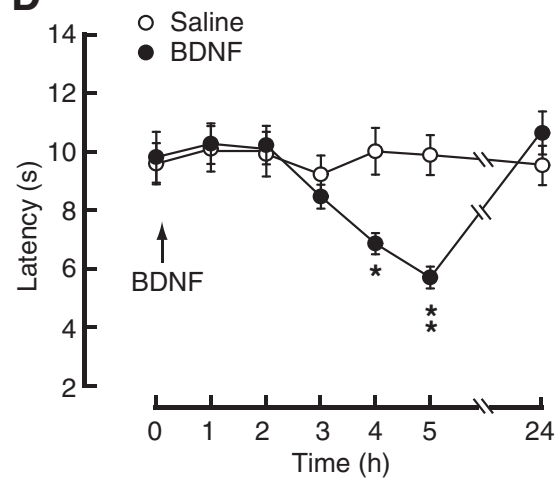

G

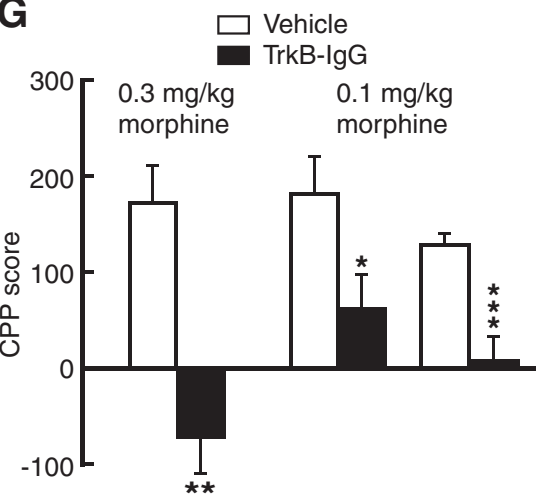

WT WT+CFA MeCP2-TG
B

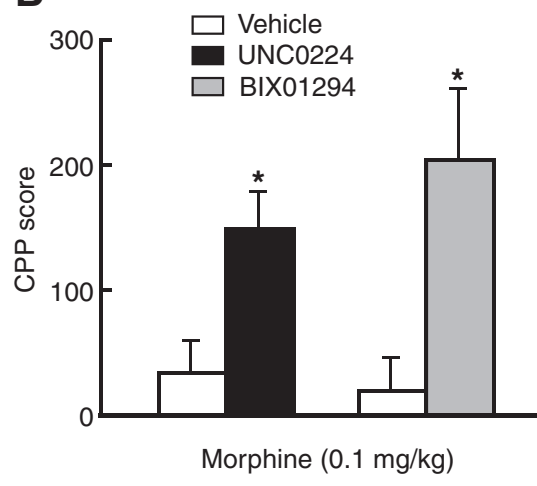

C

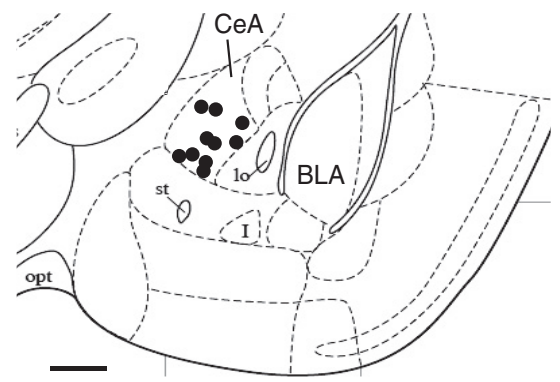

F

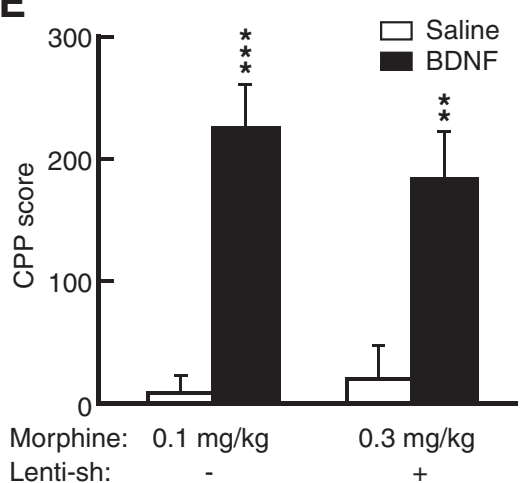

H

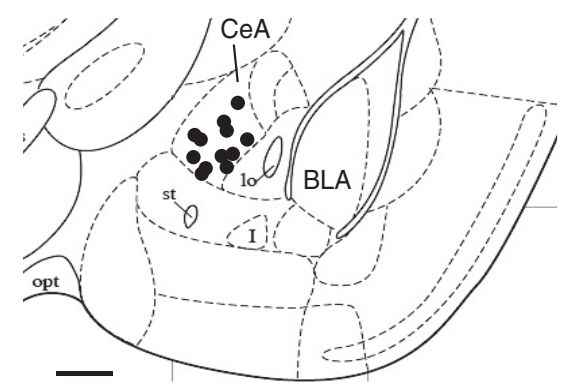

I

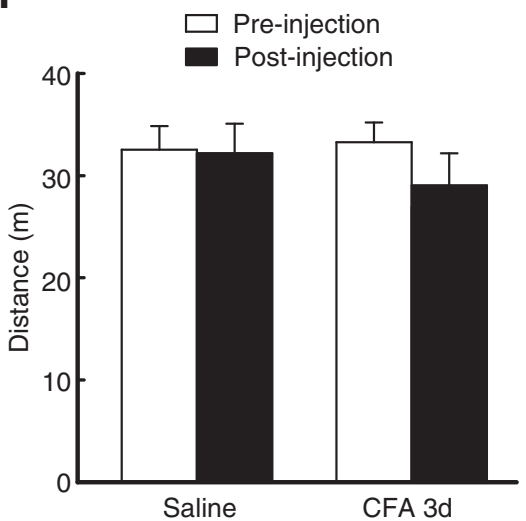

Figure 8. G9a and BDNF are involved in pain facilitation of CPP. A, Time course of CFA-induced changes in pain threshold in mice with CeA infusion of lenti-sh-MeCP2 followed by vehicle or the G9a inhibitors ( $n=5-6$ mice per group); ${ }^{*} p<0.05$ and $\# p<0.05$. B, CPP behaviors in mice conditioned with the subthreshold dose of morphine after CeA infusion of vehicle or the $G 9$ a inhibitors ( $n=5-6$ mice per group). C, Schematic drawing showing representative positions of cannula tips within the CeA for infusions of the G9a inhibitors. $D$, Changes in baseline pain threshold in mice ( $n=10$ per group) after CeA infusion of saline or BDNF. E, (PP behaviors in mice conditioned with a subthreshold dose $(0.1 \mathrm{mg} / \mathrm{kg})$ or an effective dose $(0.3 \mathrm{mg} / \mathrm{kg})$ of morphine without or with knockdown of CeA MeCP2 after CeA infusion of saline or BDNF ( $n=5-6$ mice per group). $\boldsymbol{F}$, Changes in pain threshold $3 \mathrm{~d}$ after CFA injection in mice with CeA infusion of vehicle or the BDNF inhibitor TrkB-lgG ( $n=8$ per group). G, CPP behaviors in WT mice conditioned with an effective morphine dose, in WT mice with pain and conditioned with a subthreshold morphine dose, and in MeCP2-overexpressing mice conditioned with the subthreshold morphine dose after CeA infusion of vehicle or TrkB-lgG $(n=5-10$ per group). $\boldsymbol{H}$, Schematic drawing showing representative positions of cannula tips within the CeA for infusions of BDNF and TrkB-lgG. $I$, Total distance traveled in the open field test in mice before (preinjection) and after injection (post injection) with saline or CFA ( $n=6$ each group). Scale bars: $C, 0.5 \mathrm{~mm} ; \boldsymbol{H}, 0.5 \mathrm{~mm}$.

recent study showed that chronic morphine downregulated G9a in NAc and G9a overexpression promoted analgesic tolerance and withdrawal (Sun et al., 2012). We reported previously that epigenetic mechanism of histone acetylation was involved in pain development (Zhang et al., 2011). The present study provides original evidence that $\mathrm{MeCP} 2$ and the histone methyltransferase G9a, by transcriptional de-repression of $B d n f$, play an important role in promoting pain behavior through BDNF upregulation, representing a molecular mechanism of $\mathrm{MeCP} 2$ and $\mathrm{G} 9 \mathrm{a}$ mediated methylation for the development of pain sensitization. It should be noted that G9a also methylates several nonhistone proteins (Rathert et al., 2008; Shankar et al., 2013). Thus, it is also possible that mechanisms by nonhistone proteins are involved in the behavioral effects after the G9a manipulations in this study.

An important question that remains to be answered is how chronic pain and repeated morphine activate this MeCP2-G9a 
pathway. As described in cultured cortical neurons, a cellular activity-dependent regulation of $\mathrm{MeCP} 2$ activity is $\mathrm{MeCP} 2$ phosphorylation, which releases $\mathrm{MeCP} 2$ from the promoter of its target gene, resulting in transcription activation via de-repression of the gene (Ebert et al., 2013). MeCp2 phosphorylation has also been attributed to upregulation of several genes in spinal dorsal horn neurons from a rat model of inflammatory pain (Géranton et al., 2007). While it is likely that cellular activity under the pain and opioid conditions also induces $\mathrm{MeCP} 2$ phosphorylation in $\mathrm{CeA}$, it is still unclear how MeCP2 phosphorylation for gene de-repression is related to the $\mathrm{MeCP} 2$ upregulation in conditions of pain and repeated morphine found in this study. An alternative mechanism may operate for enhanced MeCP2 repression of its target genes, as observed in this study. It would be very intriguing in future studies to identify mechanisms that link disease conditions, such as chronic pain and opioid dependence, to altered $\mathrm{MeCP} 2$ activity in the CNS.

The effects of pain on opioid reward and consequently opioid use are still unclear, not to mention the underlying mechanisms. Indeed, sustained pain or noxious stimuli can activate the brain's reward circuitry in humans (Becerra et al., 2001; Zubieta et al., 2001). Previous animal studies provide conflicting results regarding pain effects on behaviors of opioid reward. While some studies reported that animals with pain consumed less opioids in a self-administration model or displayed reduced CPP behavior (Ozaki et al., 2003; Narita et al., 2005; Martin and Ewan, 2008), other studies showed that pain increased opioid self-administration and enhanced CPP behavior (Sufka, 1994; Kupers and Gybels, 1995; Colpaert et al., 2001; Cahill et al., 2013). In this regard, an important factor to consider is the sensory and affective dimensions of pain. Behaviors of drug seeking and drug use generally involve both a positive reinforcing effect of drugs and removal of negative reinforcing effect by drug withdrawal (Koob et al., 2004). The increased sensitivity in opioid-induced CPP behavior under pain condition we observed in this study may result from pain-induced priming of the reward-regulating cascade in CeA. As pain is often associated with an aversive state and pain relief is rewarding (Fields, 2004; King et al., 2009; Neugebauer et al., 2009), it is also possible that morphine inhibition of the affective component of pain (i.e., pain relief-induced rewarding effect) contributed to the increased sensitivity, providing that CFAinduced affective pain outlasts the sensory pain (Fig. $1 F$ ) and that the low dose of morphine $(0.1 \mathrm{mg} / \mathrm{kg})$, ineffective on sensory pain (Fig. 1D), is effective in inhibiting CFA-induced affective pain. Further studies are warranted to assess this pain relief-induced rewarding effect. Interestingly, our results indicate that pain may mainly affect the initial stage of reward for learning and acquiring the behavior and may be less effective on already acquired behavior (e.g., drug self-administration).

From a clinical perspective, how pain affects use and abuse of opioid analgesics has become a pressing issue in recent years (Ballantyne and LaForge, 2007). In addition to multiple systems involved in processing of pain and drug reward, patients with chronic pain commonly develop other comorbid emotional disorders, such as depression, anxiety, and stress, which may differentially alter behaviors of opioid reward (Edlund et al., 2007). Nevertheless, by identifying molecular mechanisms for CeA functions that regulate emotional processes associated with pain and opioid reward, the current study is an initial step toward understanding the multifaceted interactions between pain experience and behaviors of opioid use.

\section{References}

Ballantyne JC, LaForge KS (2007) Opioid dependence and addiction during opioid treatment of chronic pain. Pain 129:235-255. CrossRef Medline

Basbaum AI, Bautista DM, Scherrer G, Julius D (2009) Cellular and molecular mechanisms of pain. Cell 139:267-284. CrossRef Medline

Baxter MG, Murray EA (2002) The amygdala and reward. Nat Rev Neurosci 3:563-573. CrossRef Medline

Becerra L, Breiter HC, Wise R, Gonzalez RG, Borsook D (2001) Reward circuitry activation by noxious thermal stimuli. Neuron 32:927-946. CrossRef Medline

Bie B, Zhu W, Pan ZZ (2009) Ethanol-induced delta-opioid receptor modulation of glutamate synaptic transmission and conditioned place preference in central amygdala. Neuroscience 160:348-358. CrossRef Medline

Bienvenu T, Chelly J (2006) Molecular genetics of Rett syndrome: when DNA methylation goes unrecognized. Nat Rev Genet 7:415-426. CrossRef Medline

Cahill CM, Xue L, Grenier P, Magnussen C, Lecour S, Olmstead MC (2013) Changes in morphine reward in a model of neuropathic pain. Behav Pharmacol 24:207-213. CrossRef Medline

Cai YQ, Wang W, Hou YY, Zhang Z, Xie J, Pan ZZ (2013) Central amygdala GluA1 facilitates associative learning of opioid reward. J Neurosci 33: 1577-1588. CrossRef Medline

Chahrour M, Jung SY, Shaw C, Zhou X, Wong ST, Qin J, Zoghbi HY (2008) $\mathrm{MeCP} 2$, a key contributor to neurological disease, activates and represses transcription. Science 320:1224-1229. CrossRef Medline

Chang Q, Khare G, Dani V, Nelson S, Jaenisch R (2006) The disease progression of Mecp2 mutant mice is affected by the level of BDNF expression. Neuron 49:341-348. CrossRef Medline

Chen WG, Chang Q, Lin Y, Meissner A, West AE, Griffith EC, Jaenisch R, Greenberg ME (2003) Derepression of BDNF transcription involves calcium-dependent phosphorylation of MeCP2. Science 302:885-889. CrossRef Medline

Colpaert FC, Tarayre JP, Alliaga M, Bruins Slot LA, Attal N, Koek W (2001) Opiate self-administration as a measure of chronic nociceptive pain in arthritic rats. Pain 91:33-45. CrossRef Medline

Deng JV, Rodriguiz RM, Hutchinson AN, Kim IH, Wetsel WC, West AE (2010) MeCP2 in the nucleus accumbens contributes to neural and behavioral responses to psychostimulants. Nat Neurosci 13:1128-1136. CrossRef Medline

Denk F, McMahon SB (2012) Chronic pain: emerging evidence for the involvement of epigenetics. Neuron 73:435-444. CrossRef Medline

Ebert DH, Gabel HW, Robinson ND, Kastan NR, Hu LS, Cohen S, Navarro AJ, Lyst MJ, Ekiert R, Bird AP, Greenberg ME (2013) Activitydependent phosphorylation of $\mathrm{MeCP} 2$ threonine 308 regulates interaction with NCoR. Nature 499:341-345. CrossRef Medline

Edlund MJ, Steffick D, Hudson T, Harris KM, Sullivan M (2007) Risk factors for clinically recognized opioid abuse and dependence among veterans using opioids for chronic non-cancer pain. Pain 129:355-362. CrossRef Medline

Fields H (2004) State-dependent opioid control of pain. Nat Rev Neurosci 5:565-575. CrossRef Medline

Géranton SM, Morenilla-Palao C, Hunt SP (2007) A role for transcriptional repressor methyl-CpG-binding protein 2 and plasticity-related gene serum- and glucocorticoid-inducible kinase 1 in the induction of inflammatory pain states. J Neurosci 27:6163-6173. CrossRef Medline

Gottfried JA, O’Doherty J, Dolan RJ (2003) Encoding predictive reward value in human amygdala and orbitofrontal cortex. Science 301:11041107. CrossRef Medline

Guy J, Cheval H, Selfridge J, Bird A (2011) The role of MeCP2 in the brain. Annu Rev Cell Dev Biol 27:631-652. CrossRef Medline

Hyman SE, Malenka RC, Nestler EJ (2006) Neural mechanisms of addiction: the role of reward-related learning and memory. Annu Rev Neurosci 29:565-598. CrossRef Medline

Im HI, Hollander JA, Bali P, Kenny PJ (2010) MeCP2 controls BDNF expression and cocaine intake through homeostatic interactions with microRNA-212. Nat Neurosci 13:1120-1127. CrossRef Medline

King T, Vera-Portocarrero L, Gutierrez T, Vanderah TW, Dussor G, Lai J, Fields HL, Porreca F (2009) Unmasking the tonic-aversive state in neuropathic pain. Nat Neurosci 12:1364-1366. CrossRef Medline

Koob GF, Ahmed SH, Boutrel B, Chen SA, Kenny PJ, Markou A, O’Dell LE, Parsons LH, Sanna PP (2004) Neurobiological mechanisms in the tran- 
sition from drug use to drug dependence. Neurosci Biobehav Rev 27:739749. CrossRef Medline

Kupers R, Gybels J (1995) The consumption of fentanyl is increased in rats with nociceptive but not with neuropathic pain. Pain 60:137-141. CrossRef Medline

Kynast KL, Russe OQ, Möser CV, Geisslinger G, Niederberger E (2013) Modulation of central nervous system-specific microRNA-124a alters the inflammatory response in the formalin test in mice. Pain 154:368-376. CrossRef Medline

Lewis JD, Meehan RR, Henzel WJ, Maurer-Fogy I, Jeppesen P, Klein F, Bird A (1992) Purification, sequence, and cellular localization of a novel chromosomal protein that binds to methylated DNA. Cell 69:905-914. CrossRef Medline

Li B, Carey M, Workman JL (2007) The role of chromatin during transcription. Cell 128:707-719. CrossRef Medline

Martin TJ, Ewan E (2008) Chronic pain alters drug self-administration: implications for addiction and pain mechanisms. Exp Clin Psychopharmacol 16:357-366. CrossRef Medline

Martinowich K, Hattori D, Wu H, Fouse S, He F, Hu Y, Fan G, Sun YE (2003) DNA methylation-related chromatin remodeling in activity-dependent BDNF gene regulation. Science 302:890-893. CrossRef Medline

Maze I, Covington HE 3rd, Dietz DM, LaPlant Q, Renthal W, Russo SJ, Mechanic M, Mouzon E, Neve RL, Haggarty SJ, Ren Y, Sampath SC, Hurd YL, Greengard P, Tarakhovsky A, Schaefer A, Nestler EJ (2010) Essential role of the histone methyltransferase G9a in cocaine-induced plasticity. Science 327:213-216. CrossRef Medline

Narita M, Kishimoto Y, Ise Y, Yajima Y, Misawa K, Suzuki T (2005) Direct evidence for the involvement of the mesolimbic kappa-opioid system in the morphine-induced rewarding effect under an inflammatory pain-like state. Neuropsychopharmacology 30:111-118. CrossRef Medline

Neugebauer V, Galhardo V, Maione S, Mackey SC (2009) Forebrain pain mechanisms. Brain Res Rev 60:226-242. CrossRef Medline

Ooi L, Wood IC (2007) Chromatin crosstalk in development and disease: lessons from REST. Nat Rev Genet 8:544-554. CrossRef Medline

Ozaki S, Narita M, Narita M, Iino M, Miyoshi K, Suzuki T (2003) Suppression of the morphine-induced rewarding effect and G-protein activation in the lower midbrain following nerve injury in the mouse: involvement of G-protein-coupled receptor kinase 2. Neuroscience 116:89-97. CrossRef Medline

Pan ZZ, Tershner SA, Fields HL (1997) Cellular mechanism for antianalgesic action of agonists of the kappa-opioid receptor. Nature 389: 382-385. CrossRef Medline

Passik SD, Kirsh KL (2011) Addictions in pain clinics and pain treatment. Ann N Y Acad Sci 1216:138-143. CrossRef Medline

Pezet S, McMahon SB (2006) Neurotrophins: mediators and modulators of pain. Annu Rev Neurosci 29:507-538. CrossRef Medline

Pickens CL, Airavaara M, Theberge F, Fanous S, Hope BT, Shaham Y (2011) Neurobiology of the incubation of drug craving. Trends Neurosci 34:411420. CrossRef Medline

Pitkänen A, Savander V, LeDoux JE (1997) Organization of intraamygdaloid circuitries in the rat: an emerging framework for understanding functions of the amygdala. Trends Neurosci 20:517-523. CrossRef Medline

Rathert P, Dhayalan A, Murakami M, Zhang X, Tamas R, Jurkowska R, Kom- atsu Y, Shinkai Y, Cheng X, Jeltsch A (2008) Protein lysine methyltransferase G9a acts on non-histone targets. Nat Chem Biol 4:344-346. CrossRef Medline

Robison AJ, Nestler EJ (2011) Transcriptional and epigenetic mechanisms of addiction. Nat Rev Neurosci 12:623-637. CrossRef Medline

Sadri-Vakili G, Kumaresan V, Schmidt HD, Famous KR, Chawla P, Vassoler FM, Overland RP, Xia E, Bass CE, Terwilliger EF, Pierce RC, Cha JH (2010) Cocaine-induced chromatin remodeling increases brain-derived neurotrophic factor transcription in the rat medial prefrontal cortex, which alters the reinforcing efficacy of cocaine. J Neurosci 30:1173511744. CrossRef Medline

Samaco RC, Neul JL (2011) Complexities of Rett syndrome and MeCP2. J Neurosci 31:7951-7959. CrossRef Medline

See RE, Fuchs RA, Ledford CC, McLaughlin J (2003) Drug addiction, relapse, and the amygdala. Ann N Y Acad Sci 985:294-307. Medline

Shankar SR, Bahirvani AG, Rao VK, Bharathy N, Ow JR, Taneja R (2013) G9a, a multipotent regulator of gene expression. Epigenetics 8:16-22. CrossRef Medline

Sufka KJ (1994) Conditioned place preference paradigm: a novel approach for analgesic drug assessment against chronic pain. Pain 58:355-366. CrossRef Medline

Sun H, Maze I, Dietz DM, Scobie KN, Kennedy PJ, Damez-Werno D, Neve RL, Zachariou V, Shen L, Nestler EJ (2012) Morphine epigenomically regulates behavior through alterations in histone $\mathrm{H} 3$ lysine 9 dimethylation in the nucleus accumbens. J Neurosci 32:17454-17464. CrossRef Medline

Sun YE, Wu H (2006) The ups and downs of BDNF in Rett syndrome. Neuron 49:321-323. CrossRef Medline

Tochiki KK, Cunningham J, Hunt SP, Géranton SM (2012) The expression of spinal methyl-CpG-binding protein 2, DNA methyltransferases and histone deacetylases is modulated in persistent pain states. Mol Pain 8:14. CrossRef Medline

Tzschentke TM (2007) Measuring reward with the conditioned place preference (CPP) paradigm: update of the last decade. Addict Biol 12:227462. CrossRef Medline

Urban R, Scherrer G, Goulding EH, Tecott LH, Basbaum AI (2011) Behavioral indices of ongoing pain are largely unchanged in male mice with tissue or nerve injury-induced mechanical hypersensitivity. Pain 152: 990-1000. CrossRef Medline

Woolf CJ, Hashmi M (2004) Use and abuse of opioid analgesics: potential methods to prevent and deter non-medical consumption of prescription opioids. Curr Opin Investig Drugs 5:61-66. Medline

Yasui DH, Peddada S, Bieda MC, Vallero RO, Hogart A, Nagarajan RP, Thatcher KN, Farnham PJ, Lasalle JM (2007) Integrated epigenomic analyses of neuronal MeCP2 reveal a role for long-range interaction with active genes. Proc Natl Acad Sci U S A 104:19416-19421. CrossRef Medline

Zhang Z, Cai YQ, Zou F, Bie B, Pan ZZ (2011) Epigenetic suppression of GAD65 expression mediates persistent pain. Nat Med 17:1448-1455. CrossRef Medline

Zubieta JK, Smith YR, Bueller JA, Xu Y, Kilbourn MR, Jewett DM, Meyer CR, Koeppe RA, Stohler CS (2001) Regional mu opioid receptor regulation of sensory and affective dimensions of pain. Science 293:311-315. CrossRef Medline 